\title{
Sedimentology and depositional architecture of tufas deposited in stepped fluvial systems of changing slope: Lessons from the Quaternary Añamaza valley (Iberian Range, Spain)
}

\author{
CONCHA ARENAS, MARTA VÁZQUEZ-URBEZ, GONZALO PARDO \\ and CARLOS SANCHO \\ Dpto. de Ciencias de la Tierra, Universidad de Zaragoza, C/Pedro Cerbuna 12, Zaragoza 50009, Spain \\ (E-mail: carenas@unizar.es)
}

Associate Editor - Anna Gandin

\begin{abstract}
The Pleistocene and Holocene tufas of the Añamaza valley (stepped buildups, up to $70 \mathrm{~m}$ thick, along the valley) consist of several depositional stages separated by erosional surfaces. Eight associations of tufa and related carbonate facies, plus minor polygenic detrital facies, represent the processes that occurred in different fluvial and related environments. The bedrock lithology and structure controlled the location of the knickpoints along the valley and allowed separation of two stepped stretches with distinct conceptual facies models. The moderate-slope model includes extensive standing-water areas dammed by barrage-cascades. In the lakes, bioclastic silts, sands and limestones along with phytoclastic and marly, at places peaty, sediments formed. Abundant stem phytoherms account for extensive palustrine areas. The high-slope model consists of smaller dammed areas between close-up cascades and barrage-cascades, which were composed primarily of moss phytoherms and phytoclastic tufas. An outstanding feature is the extensive steep reach with phytoclastic and polygenic detrital sediments, and stepped cascades consisting of stromatolitic and moss phytoherms. There, the steep slope limited the preservation of stem phytoherms and favoured erosion. The geometry and thickness of the sedimentary fill (wedge-shaped units composed of cascade and barrage-cascade deposits downstream, and dammed and gentle-sloped channel deposits upstream) are therefore different for each model. Multi-storey wedges are a distinctive feature of the highslope model. The initial knickpoint geometry and the tufa aggradation/progradation ratio on such steep surfaces (for example, related to changes in discharge) controlled the growth style of the cascades or barrage-cascades and, hence, the extent, thickness and vertical evolution of the upstream deposits. The sedimentological attributes and stable-isotope composition of the carbonate facies suggest a higher and more variable precipitation/evaporation ratio during the Pleistocene than during the Holocene, consistent with an overall decrease in the river discharge. This evolution was coupled with warm conditions, which prevailed during the stages of tufa formation. These results may help to assess architectural patterns in interpreting other basins, and underscore the significance of tufas as records of past hydrology and climate.
\end{abstract}

Keywords Fluvial tufa depositional architecture, hydrology and climate, Pleistocene and Holocene, river slope changes, sedimentary facies models. 


\section{INTRODUCTION}

Quaternary tufa deposits are observed in many regions of the world and are an outstanding feature in many Mediterranean and other semiarid regions (Viles \& Goudie, 1990; Pentecost, 1995; Ford \& Pedley, 1996; Viles \& Pentecost, 2007; Pedley, 2009; Arenas-Abad et al., 2010). The formation of tufa deposits is commonly associated with the dynamics of karstic systems developed within karstified, extensive carbonate units. The Iberian Range (Spain) is home to thick and extensive Quaternary tufa deposits that developed from fluvial systems fed by aquifers held in Mesozoic carbonate formations (Ordóñez et al., 1986; Coloma et al., 1996; Sancho et al., 1997; Valero-Garcés et al., 2008; Ortiz et al., 2009; Vázquez-Urbez et al., 2010, 2011, 2012; among others). The Añamaza River valley is of special importance because of the thickness of its Quaternary tufa deposits and the existence of distinct depositional stages (Arenas et al., 2009, 2010; Vázquez-Urbez et al., 2011).

The Quaternary tufas of the Añamaza valley fit the barrage-cascade model (Pedley, 1990, 2009) or the stepped fluvial system (Arenas-Abad et al., 2010). However, some particular features, which have not been yet described, make these tufas unique: (i) the existence of several depositional stages that span the Middle-Late Pleistocene and Holocene epochs; (ii) the different gradient through the valley, which enables differentiation between two distinct depositional models; (iii) the presence of deposits that are indicative of extensive steep channel stretches along the valley; and (iv) the evolution through time of these steep-channel or ramp-like areas, which conform to an aggrading-prograding process.

The correlation of deposits throughout a basin (for example, through mapping and absolute chronology) and/or the correlation of sections and/or intervals within a single deposit (for example, through depositional and erosional surfaces) provide information about the different depositional stages present. Correlations are also the basis for constructing sedimentary facies models and establishing the spatio-temporal evolution of the basins.

Detailed stratigraphical and sedimentological analyses provide crucial information on some extrinsic and intrinsic factors that control tufa formation, for example, the local hydrology and morphology (i.e., size and slope) of the sedimentation areas, which are inferred from the spatial distribution and abundance of some diagnostic facies and from the geometry and thickness of the deposits (Pedley et al., 2000; Martín-Algarra et al., 2003; Vázquez-Urbez et al., 2012). Furthermore, the morphology and deposition rate of cascade and barrage deposits have been used as indicators of changes in water discharge conditions (Pedley et al., 1996; Viles \& Pentecost, 1999). In addition, valuable climatic information can also be obtained from the abundance of certain facies and the frequency of erosional features (Viles et al., 2007). In some cases, the bulk stable isotope composition of tufas and associated facies can be a useful tool for discerning climate conditions through time (Garnett et al., 2004; Smith et al., 2004; Arenas et al., 2007). The stable isotope composition of some laminated facies provides significant information about short-term climate changes (for example, seasonal, interannual and decadal scales) (Lojen et al., 2004; Andrews, 2006; Osácar et al., 2013), but this is outside the scope of this work.

In this study, the Quaternary tufas of the Añamaza valley (Iberian Range) were characterized by means of stratigraphical, chronological and sedimentological analyses, along with stable isotope analysis of the carbonate facies. The aims of these analyses were as follows: (i) to determine the different depositional stages recorded by several build-ups; (ii) to construct sedimentary facies models that explain the formation of tufas in a stepped fluvial system with changing slope through space; and (iii) to discuss the influence of intrinsic and extrinsic factors on the formation of such tufas and associated deposits, such as the geometry of knickpoints (i.e., reaches of abrupt change in slope along the longitudinal profile), climate and river discharge. The results from these analyses will help decipher the sedimentological features of other fluvial tufa systems and, therefore, infer their topographical, hydrological and climatic context. On a broad scope, the aim of this study was to assess the environmental significance of fluvial tufa deposits in the sedimentary record.

\section{GEOGRAPHICAL AND GEOLOGICAL CONTEXT}

The Añamaza River (north-western part of the Iberian Range) flows between its headwater springs in Añavieja [960 m above sea-level (m a.s.l.)] and its mouth into the Alhama River ( $460 \mathrm{~m}$ a.s.l.), which is a tributary of the Ebro River (Fig. 1A). The Añamaza River drainage area occupies approximately $318 \mathrm{~km}^{2}$; its maximum altitude reaches $1719 \mathrm{~m}$ a.s.l. 
The climate of the Añamaza River valley is continental Mediterranean with strong seasonal contrasts. The annual mean temperature is $11 \cdot 1^{\circ} \mathrm{C}$, and the annual mean rainfall is $c a$ $564 \mathrm{~mm}$, but there are large interannual variations. Precipitation is irregularly distributed, with maximum precipitation occurring in April/ May and October. The maximum temperature is reached in July and August (mean $\approx 20 \cdot 5^{\circ} \mathrm{C}$ ), and the minimum temperature occurs in December and January (mean $\approx 4 \cdot 2^{\circ} \mathrm{C}$ ) (Data from 2007 to 2010, from Agencia Estatal de Meteorología, Spain; http://www.aemet.es/es/).

The bedrock is composed of Middle-Upper Jurassic marine limestones and marls and Uppermost Jurassic-Lower Cretaceous carbonate and siliciclastic, primarily continental, rocks (Weald facies; Tera and Oncala Groups, Mas et al., 2011) which are affected by folds and faults with north-west to south-east trends (Fig. 1A and B). Tertiary detrital deposits (conglomerates, sandstones and mudstones) and limestones, some of which are tufa, overlie the sequence. The lithological contrast among the different Mesozoic deformed rocks, and between those and the Tertiary horizontal, less resistant rocks, controls the general topographical profile and the location of the knickpoints along the present river course. The mean slope is approximately $1.9 \%$, although it is highly variable along the valley, with long spans of approximately $5 \cdot 6 \%$ (Fig. 1C).

Several isolated Quaternary stepped tufa deposits occur from Dévanos to $C a 5.5 \mathrm{~km}$ downstream of this village (Fig. 1B and C). These deposits unconformably overlie the bedrock and, in turn, appear incised by the present river. The first chronological data for these tufa deposits (Arenas et al., 2009, 2010) suggest that they formed over several periods that correlate to the marine isotope stages (MISs; Shackleton \& Opdyke, 1973) 8, 7, 5 (Pleistocene) and 1 (Holocene). Most tufas present in the area correspond to MIS 5.

Carbonate marine units from the Middle and Upper Jurassic form the fissured karstic aquifer that feeds the headwater springs of the Añamaza River. This aquifer is semi-confined by the Uppermost Jurassic-Lower Cretaceous Weald facies (Coloma et al., 1996). The estimated discharge of these springs varies between $200 \mathrm{~L} \mathrm{~s}^{-1}$ and $500 \mathrm{~L} \mathrm{~s}^{-1}$ (Sáenz-Ridruejo \& Sanz-Pérez, 1989; Coloma et al., 1996).

At present, the Añamaza River waters are primarily of the $\mathrm{SO}_{4}-\mathrm{HCO}_{3}$-Ca type, with conductivity values between 624 and $866 \mu \mathrm{S} \mathrm{cm}^{-1}$. The mean tufa deposition rate measured every six months from April 2007 to March 2010 was $5.5 \mathrm{~mm} \mathrm{yr}^{-1}$. During that period, the mean annual discharge was $210 \mathrm{~L} \mathrm{~s}^{-1}$ (gauging point of Dévanos; data from Conderación Hidrográfica del Ebro, Spain; http://195.55.247.237/saihebro/) and the calcite precipitation was first detected between Dévanos and the AÑA M site (Fig. 1B) and greatly increased downstream (VázquezUrbez et al., 2011).

\section{METHODS}

The stratigraphical analysis and the detailed study of the tufa and associated facies, in addition to the study of their lateral and vertical relations and their geometry within the deposits, formed the basis for constructing the sedimentary models. By using the available datings for the main tufa outcrops, the time of generation of different tufa build-ups was ascertained, allowing those that are physically disconnected to be correlated with one another. Eight stratigraphical sections were measured in several tufa build-ups and numerous observations were made in some others. These data were complemented by detailed sedimentological analyses of selected outcrops.

Different carbonate facies were collected for textural, mineralogical and stable isotope analyses. A total of 80 thin sections were prepared at the Servicio de preparación de rocas y materiales duros of the Servicios de Apoyo a la Investigación of the University of Zaragoza, Spain (SAI) for inspection by optical microscopy. Twenty-five samples were examined by scanning electron microscopy (SEM) using a JEOL JSM 6400 (JEOL Limited, Tokyo, Japan) and a Carl Zeiss MERLIN ${ }^{\mathrm{TM}}$ (Carl Zeiss Group, Jena, Germany) of the SAI. Fifty-four calcite samples were selected for oxygen and carbon stableisotope composition analysis. Before performing these analyses, the mineralogy of ground samples $(53 \mu \mathrm{m})$ was determined using an X-ray diffractometer (D-Max Rigaku; Rigaku Corporation, Tokyo, Japan) of the SAI. The samples were composed of almost pure calcite with trace amounts $(<2 \%)$ of quartz, phyllosilicates and iron-sulphur minerals (for example, pyrite). The isotopic analyses were performed at the Laboratorio de análisis de isótopos estables of the University of Salamanca (Spain) using a VGIsotech Sira-II mass spectrometer (Micromass Limited, Manchester, UK), following standard 

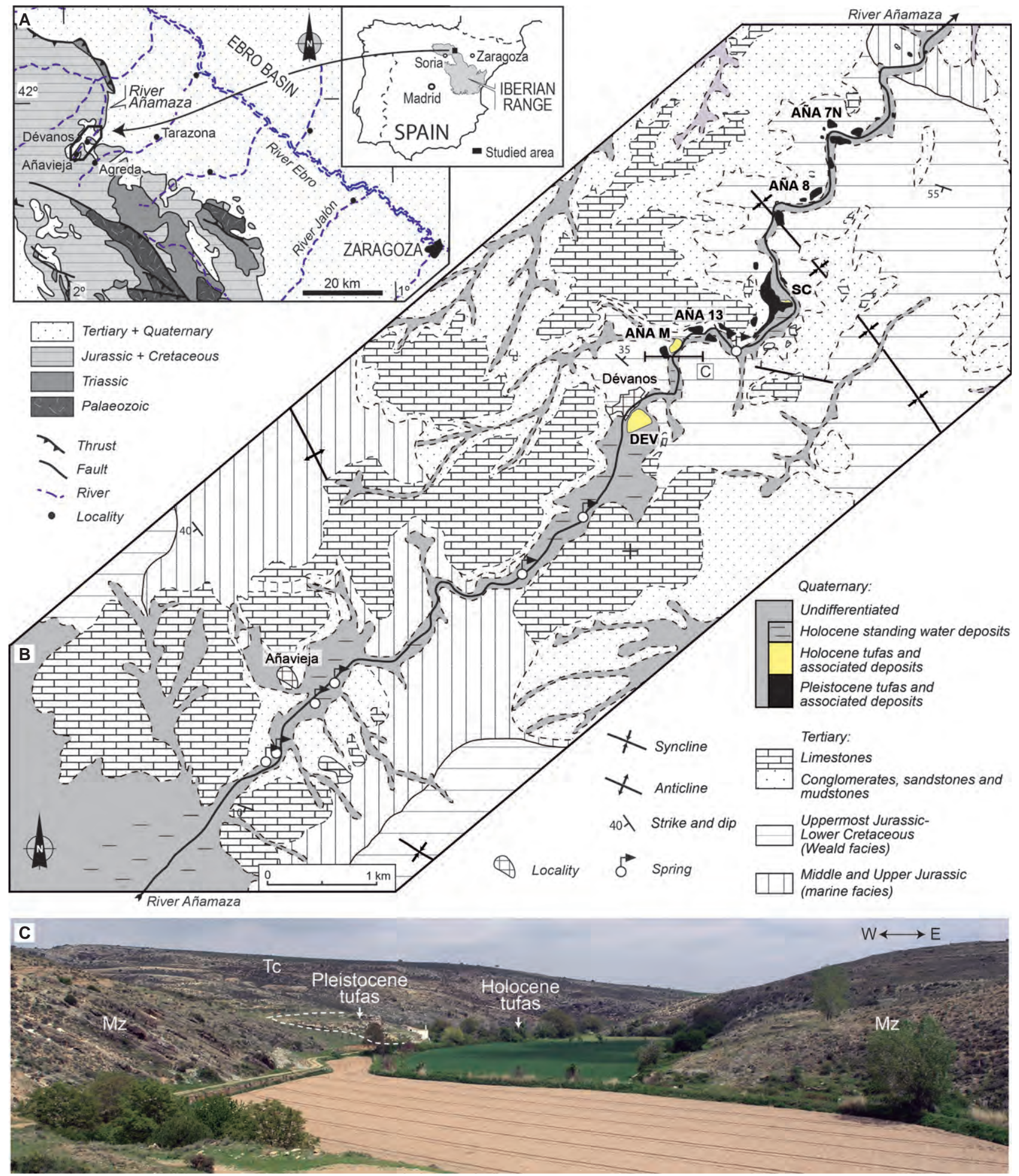

Fig. 1. Geographical and geological context of the study area. (A) Location context in the Iberian Range and Ebro Basin. (B) Geological mapping of bedrock units (based on Rey de la Rosa \& Rivera-Navarro, 1981) and Quaternary tufas and associated deposits. The names designate the most representative outcrops that are considered in this work. Note that DEV corresponds to DEB in a previous publication by Arenas et al. (2010). (C) Northward view of the Añamaza valley (east-west section located in Fig. 1B). The arrowed Holocene tufas correspond to AÑA M build-up. Note the extensive flat areas (used for agriculture works) that are occupied by grey-coloured and beigecoloured, fine sediments, which were deposited in standing water areas during the Holocene. Mz: Mesozoic strata. Tc: Tertiary strata. 
methods (McCrea, 1950). Repeated analyses of both international (NBS-19, GISP and SLAP) and internal reference materials (SM and EEZ-1), interspersed with unknown samples, indicate an overall reproducibility better than $\pm 0 \cdot 1 \%$. The results are reported in $\delta \%$ notation relative to the V-PDB (Vienna Pee Dee Belemnite).

\section{STRATIGRAPHY}

The studied Quaternary record lies over the Mesozoic and Tertiary rocks through an angular unconformity; in some measured sections the base of the Quaternary deposits does not crop out. Figures 2 to 6 present the most representative sections. Single build-ups range from a few metres to $\mathrm{ca} 70 \mathrm{~m}$ thick. This record consists of dominant carbonates lying over less abundant detrital deposits formed by conglomerates and, occasionally, mudstones. The coarse detrital sediments (polygenic conglomerates and gravels) are associated with erosional surfaces that can appear at the base of the tufa successions. These sediments also permit the distinction of several depositional stages. The tufa build-ups of the Añamaza valley are mostly physically disconnected, which hinders establishing any traditional physical correlation and, therefore, the relative stratigraphical position of these deposits. Thus, the correlation among the different buildups was based primarily on absolute datings. The chronological data used in this work are those provided by Arenas et al. (2010) for the outcropping deposits, and those provided from drilling logs by Luzón et al. (2011) for the non-outcropping Holocene deposits.

\section{Pleistocene deposits}

The Pleistocene deposits crop out along the middle stretch of the valley (north-east of Dévanos; Fig. 1B) and represent the majority of the outcropping Quaternary record. The Salto del Cajo build-up (SC in Fig. 1B) is unique because of its great extension and thick sediments. This build-up has a general wedge shape that widens northwards, reaching up to $c a 70 \mathrm{~m}$ in thickness and $c a 0.3 \mathrm{~km}$ wide. For this deposit, a physical correlation was established among the four measured sections (Fig. 2A and B) based on the continuity of some erosional and depositional surfaces. This correlation allowed the distinction of several depositional bodies that correspond to five stages separated by ero- sional surfaces (S1 to S4). These stages represent the complex filling of a steep stretch of the Añamaza River valley by tufas and associated carbonate facies and, to a lesser extent, by detrital materials (polygenic conglomerates and minor mudstones), following four strong incision events, plus the initial incision at the bottom (not visible in Fig. 2).

The chronological data for several intervals at the Salto del Cajo build-up agree with the abovementioned physical correlation (Fig. 2A). The first depositional stages are dated as $282.5 \pm 6.9 \mathrm{ka}$ (base of section C-1) and 204.3 \pm 7 ka (base of section C-4), and the rest of the depositional stages are dated between $120 \cdot 8 \pm 4 \mathrm{ka}$ and $81 \pm 17 \mathrm{ka}$, considering the reliable datings. The age of the base of section C-3 is probably incorrect. Therefore, this build-up records tufa formation during MISs 8,7 and 5 (Arenas et al., 2010) but, according to the Gibbard et al. (2005) marine isotope stages, the age of $282.5 \pm 6.9 \mathrm{ka}$ is now placed within MIS 9.

The extensive deposits observed in the Las Parideras sector are other examples of Pleistocene tufa outcrops in the valley (ANA 13, see Fig. 1B for location). In this part of the valley, a wedge-shaped tufa build-up (Fig. 4), which is ca 17 m thick, lies unconformably over Mesozoic rocks and other limestones, including tufas, which are perhaps Tertiary in age. The latter are associated with polygenic detrital deposits, and both form a complex arrangement of units; their study is beyond the objectives of this work (Fig. 4A). The base of the Quaternary tufa build-up almost reaches the course of the present-day river. Figure 4 shows a stratigraphical section and illustrates the outcrop. The age of this outcrop is between $83.5 \pm 18.9 \mathrm{ka}$ and $105.8 \pm 3.9 \mathrm{ka}$, which places the AÑ 13 sector within MIS 5 (Arenas et al., 2010).

In the northern half of the studied area, other tufa deposits crop out (for example, AÑA 7N and AÑA 8, see Fig. 1B for location); their thickness ranges between $10 \mathrm{~m}$ and $35 \mathrm{~m}$. Reliable datings yielded an age of $129.9 \pm 11.1$ to $99.6 \pm 1.8 \mathrm{ka}$ for ANA $7 \mathrm{~N}$, and $119 \cdot 1 \pm 2 \cdot 5$ ka for AÑ 8 (i.e., within MIS 5; Arenas et al., 2010). Figure 5 shows the AÑA $7 \mathrm{~N}$ section.

\section{Holocene deposits}

Most Holocene deposits appear in the upper stretch of the valley (south-west of Salto del Cajo; Fig. 1B). The outcropping tufa and associated deposits lie in angular unconformity over Mesozoic rocks, but they are also encased in 

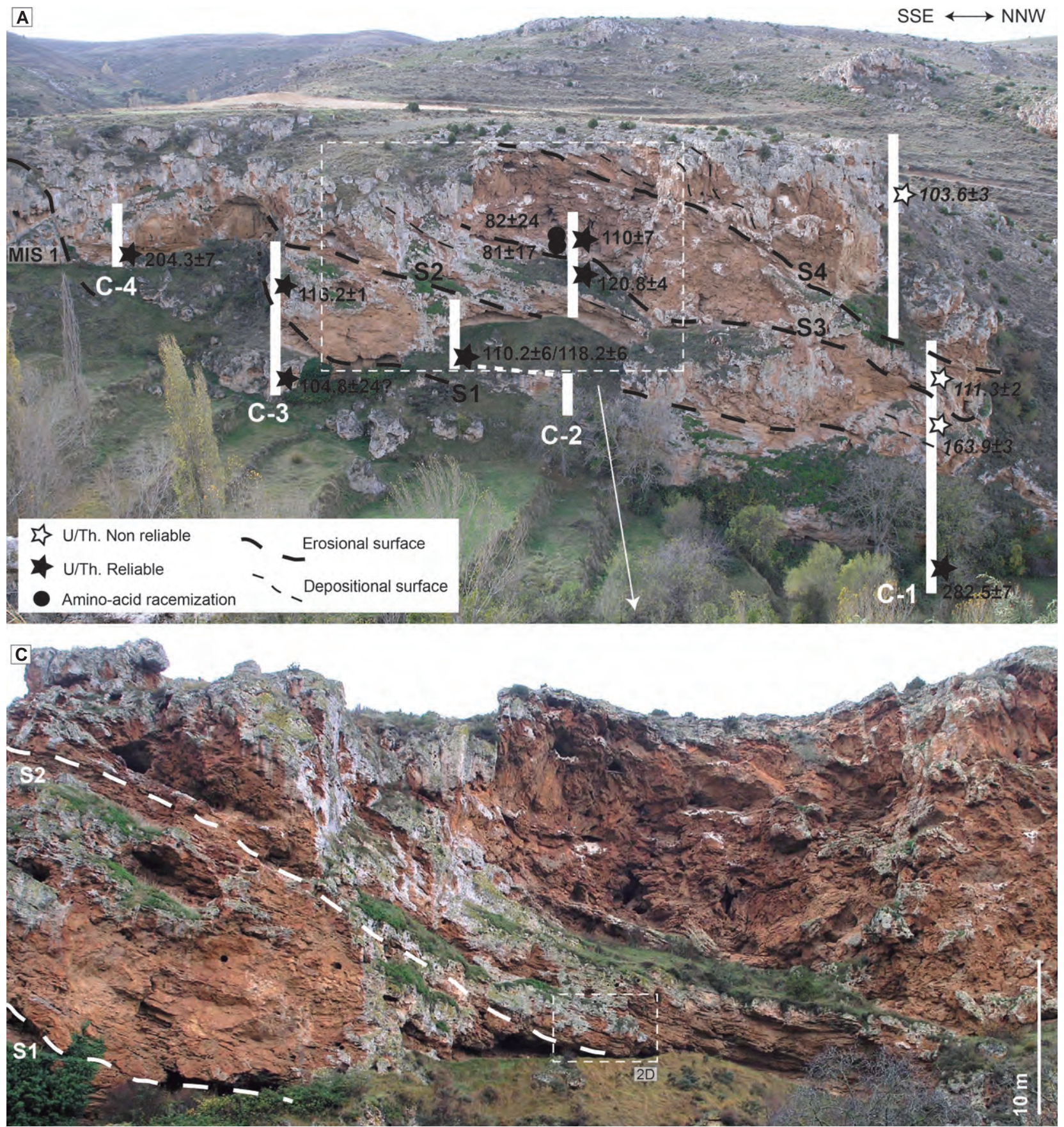

Fig. 2. Salto del Cajo site (SC in Fig. 1B). (A) Field view of the northern Salto del Cajo build-up, with location of the stratigraphical sections and ages of samples that have been dated (chronological data in ka, from Arenas et al., 2010). Note the presence of deposits of MIS 1 at the southern part of the outcrop (position of dated sample is in Fig. 7F). (B) Stratigraphical sections measured at the northern part of the Salto del Cajo build-up. Their correlation is based on the continuity of erosional (S1 to S4) and depositional surfaces, as indicated in (A). (C) Detail of (A) showing erosional surfaces (S1 and S2) and wedge-shaped bodies (FA 1, Fig. 9). (D) Detail of a wedge-shaped body over a detrital deposit (facies G). In (C) and (D), round cavities represent voids from decayed trunks and branches. (E) Small bioherm made of layers of mosses alternating with thinner layers of fine phytoclasts. Texture and lithology of stratigraphical sections: Gy: gypsum; M: mudstone; W: wackestone; P: packstone; G: grainstone; B: boundstone; F: floatstone; R: rudstone. M-F: marls and fines; S: sand; G: gravel. 


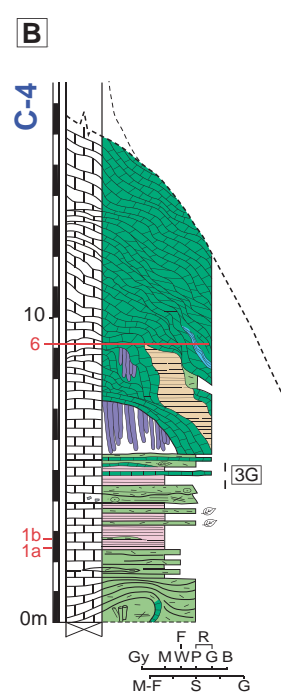

$\because 0$ Conglomerates $(\mathrm{G})$

$=\overline{=}$ Mudstones (F)

+- Marls (M)

$=$ Carbonate silts

and sands (Sb)

II Limestones (L)

Peaty matter

๑) Oncoids (Lo)

(Atromatolites (LS)

(17) Ris? Vertical stems (Lst 1)

Bryophytes, moss layers (Lbr)

3 Entwined bryophytes and other macrophytes (Lbr)

Hanging stems (Lst 2)
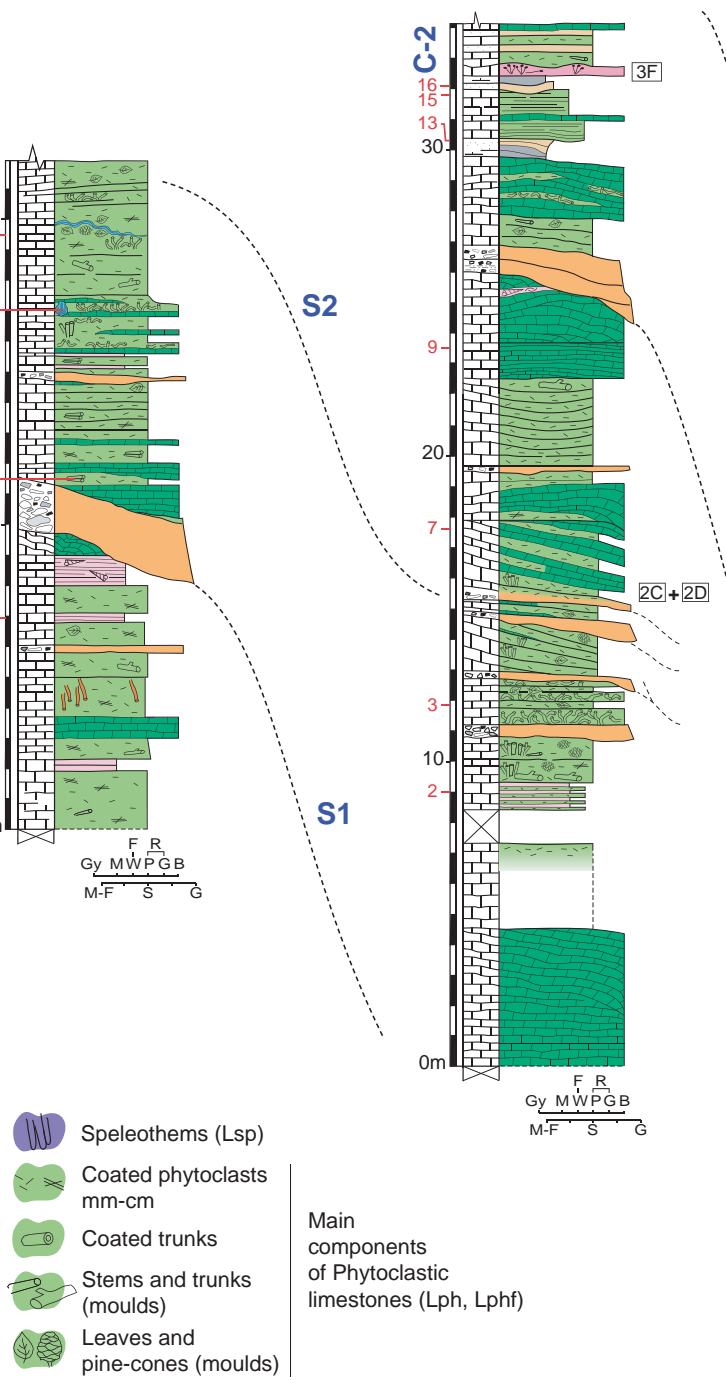

$\curvearrowright$ Ostracods

(6) Gastropods

(... Charophyte debris

Main

components

of Bioclastic

limestones (Lb)

2. Charophytes in situ (Lch)

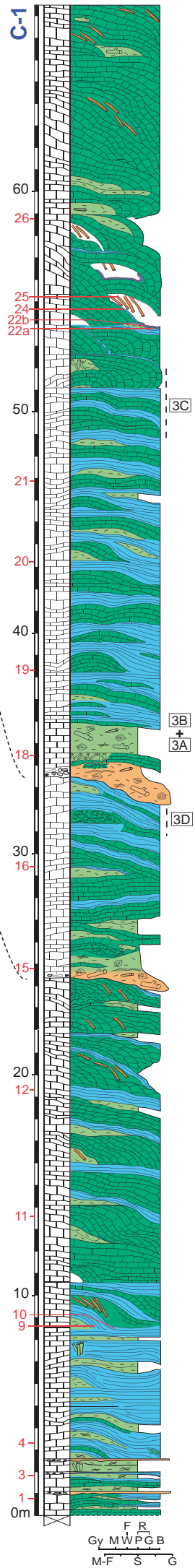

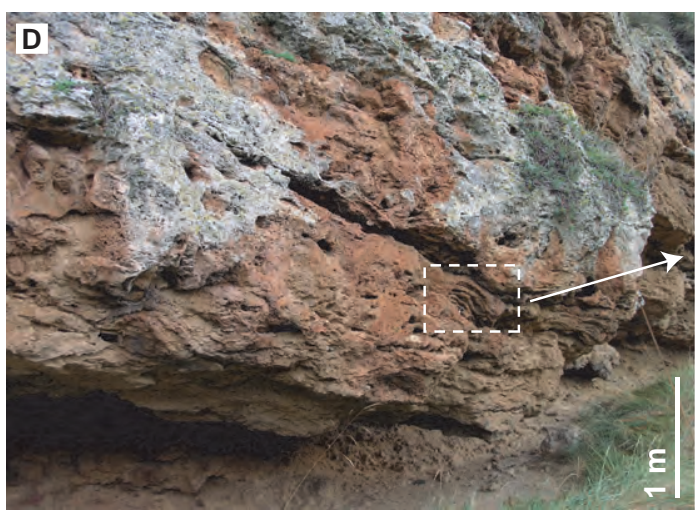

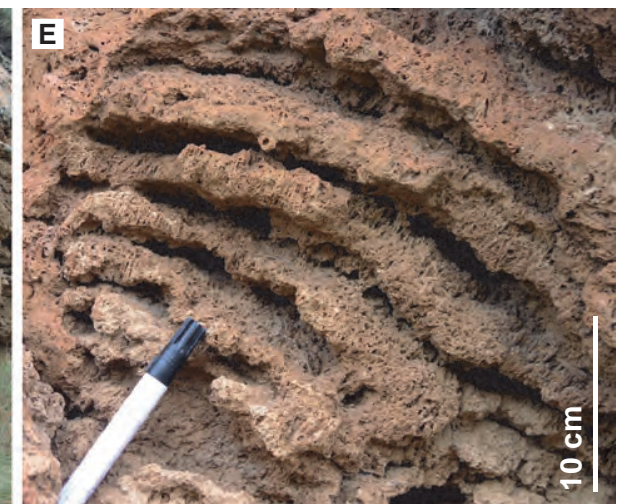

(4) Eggshells

4h Bioturbation

3C Figure 3C

1- Stable-isotope samples
S4

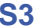

S3

\section{$+$}

3

\section{.}

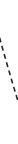



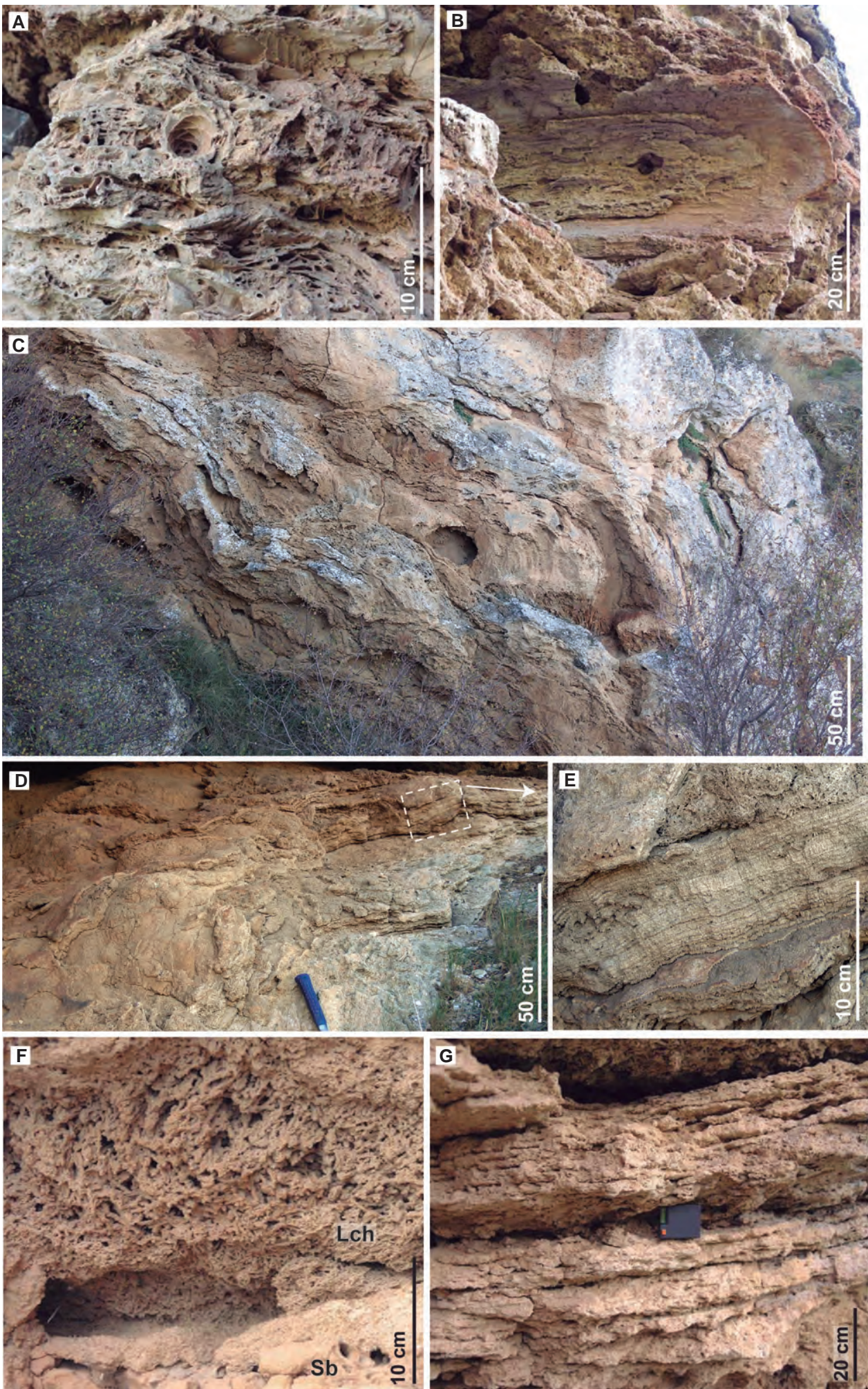

Fig. 3. Field views of the Salto del Cajo site (SC in Fig. 1B). (A) Phytoclastic tufa. Note the abundance of leaf and pine-cone imprints. (B) Trunk mould within phytoclastic tufa deposits. (A) and (B) are in section C-1. (C) Bioherms of stromatolites and bryophytes formed in a stepped cascade (multi-domed surfaces; FA 2, Fig. 9) that evolved to vertical cascades through time. Approximate location is indicated in section C-1. (D) Detail of a stepped cascade deposit mostly made of stromatolites (section C-1). (E) Detail of (D): stromatolites overlain by a small phytoherm of intertwined stems. (F) Bioherm of charophytes (Lch) over laminated carbonate sands (Sb) in section C-2. (G) Deposits of bioclastic and intraclastic limestones with horizontal lamination and banding (base of section C-4). 

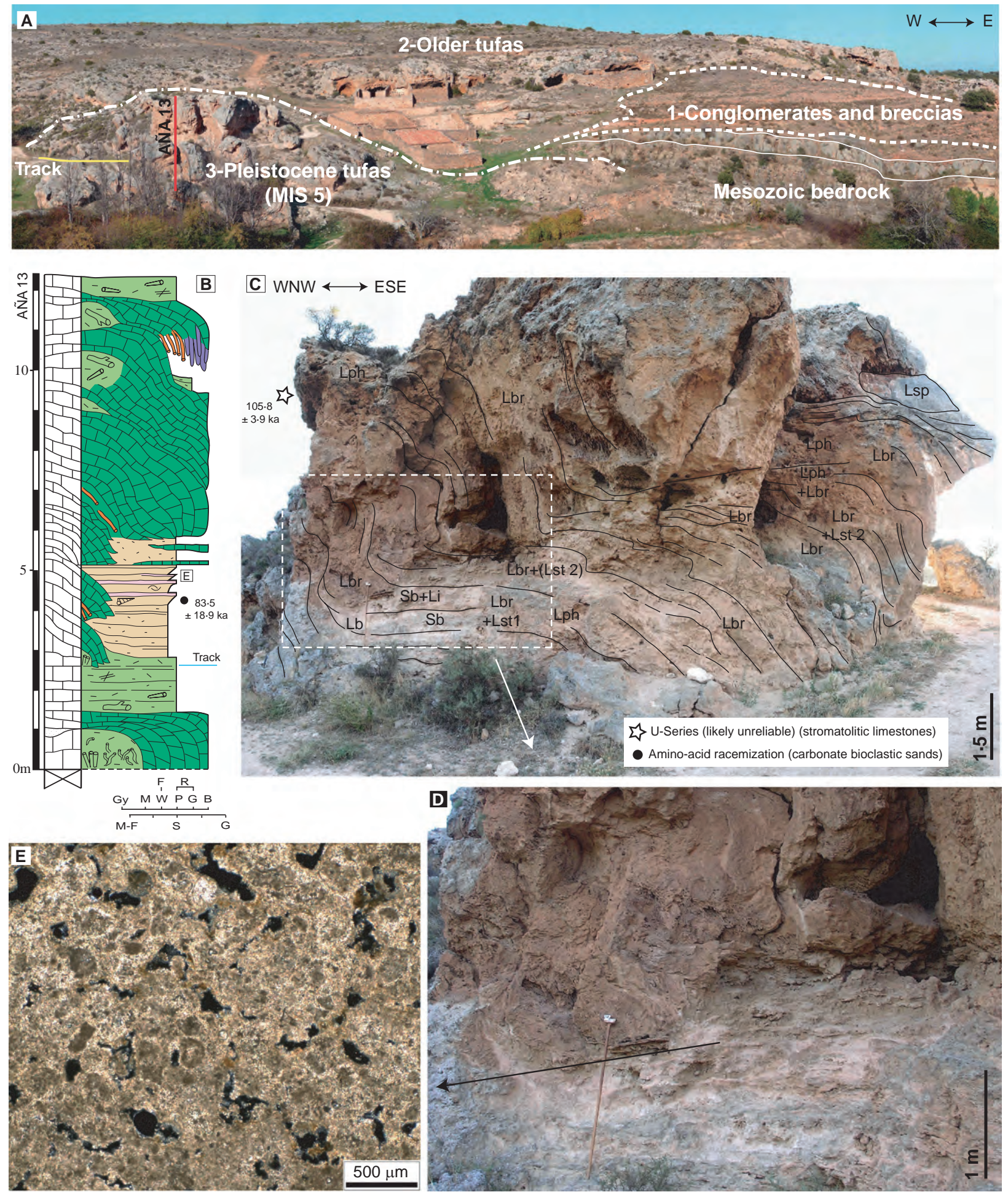

Fig. 4. Las Parideras site (AÑA 13 in Fig. 1B). (A) Panoramic view showing the unconformable disposition of the studied Pleistocene tufas with respect to older deposits: polygenic detrital deposits and horizontal limestones, part of which are tufas ( 1 and 2, probably Tertiary in age); the detrital deposits, in turn, lie in angular unconformity over the folded Mesozoic strata. (B) Stratigraphical section measured at the AÑA 13 build-up. (C) Field view of the AÑA 13 section from the track. In (B) and (C), chronological data are from Arenas et al. (2010). (D) Closeup view of bioherms of mosses (prograding cascade) and laterally related bioclastic sands (Sb) and interbedded bioclastic and intraclastic limestones (Lb, Li). (E) Photomicrograph of intraclastic limestones. Legend of symbols in Fig. 2. Texture and lithology of stratigraphical section: Gy: gypsum; M: mudstone; W: wackestone; P: packstone; G: grainstone; B: boundstone; F: floatstone; R: rudstone. M-F: marls and fines; S: sand; G: gravel.

(C) 2013 The Authors. Journal compilation (C 2013 International Association of Sedimentologists, Sedimentology, 61, 133-171 


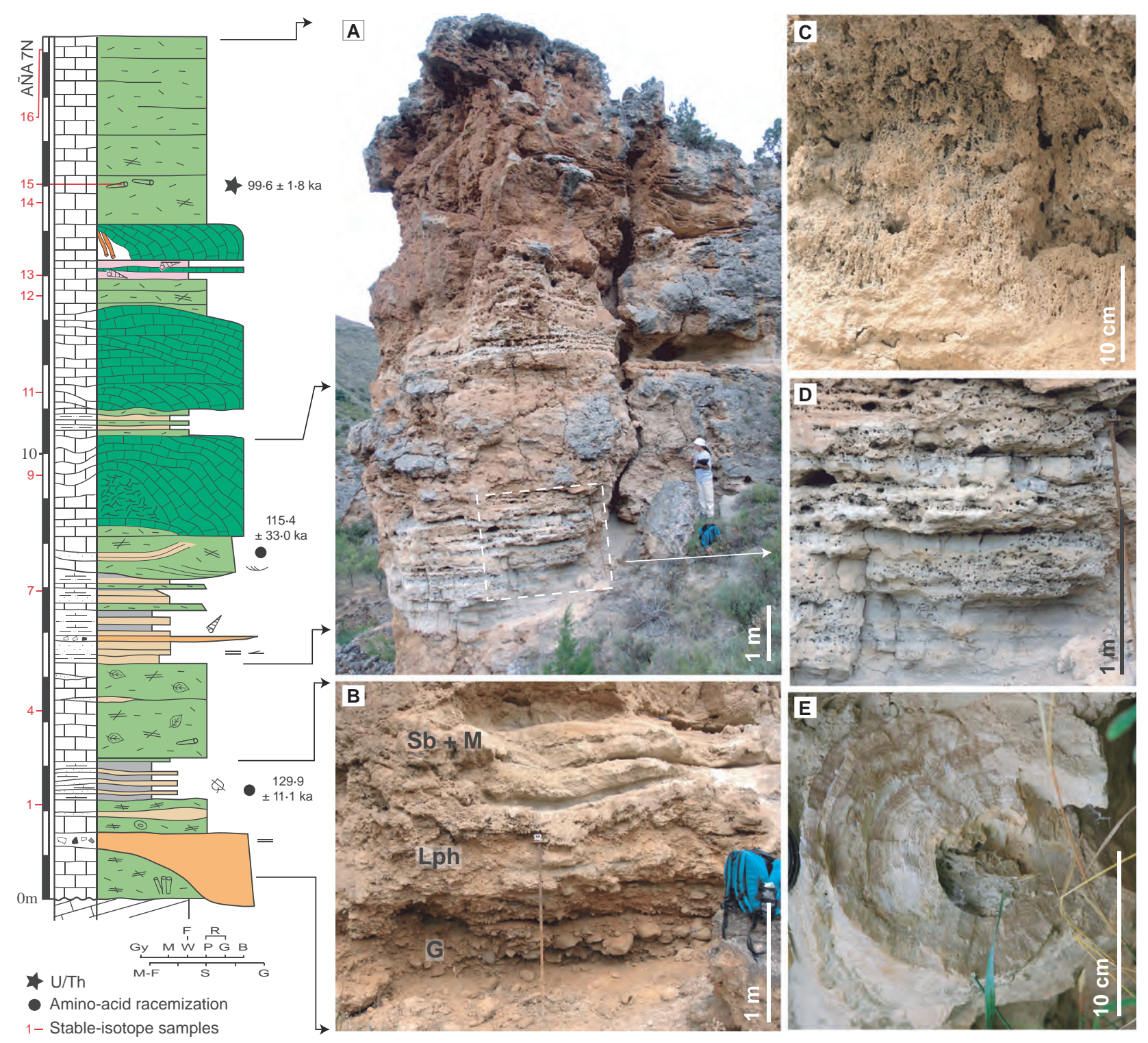

Fig. 5. Stratigraphical section of the AÑA 7N build-up (Fig. 1B). Chronological data from Arenas et al. (2010). (A) to (D) Field views of the section. (B) Conglomerates (G) followed by phytoclastic tufas (Lph) and an alternation of bioclastic sands, silts and marls (Sb and M) (FA 6). (C) Detail of moss layers in a phytoherm. (D) Bioclastic sands and silts and marls with horizontal lamination and banding. (E) Laminated coating (stromatolitic) of a stem of AÑA 8 build-up (Fig. 1B). Legend of symbols in Fig. 2. Texture and lithology of stratigraphical section: Gy: gypsum; M: mudstone; W: wackestone; P: packstone; G: grainstone; B: boundstone; F: floatstone; R: rudstone. M-F: marls and fines; S: sand; G: gravel.

Pleistocene tufas, such as those of El Molino (AÑA M; Figs 1C and 6) and Salto del Cajo (SC; Figs 2A and 7F). The Holocene outcropping build-ups of tufa and associated facies are those of El Molino (AÑA $\mathrm{M}$ in Fig. 1B), up to $8 \mathrm{~m}$ thick (Fig. 6) and Dévanos (DEV in Fig. 1B), $c a$ 8 to $10 \mathrm{~m}$ thick (Fig. 7A to E). Dating of several samples yielded ages of $10 \cdot 6 \pm 3 \cdot 3 \mathrm{ka}$ and $10 \cdot 5 \pm 4.4 \mathrm{ka}$ in Dévanos, and between $7 \cdot 7 \pm 3 \cdot 8$ $\mathrm{ka}$ and $1.7 \pm 0.03 \mathrm{ka}$ in El Molino; all of the dates are within MIS 1 . In addition, the tufa deposits encased in the Salto del Cajo Pleistocene build-up (eastern part of SC in Fig. 1B) yielded an age of $1.5 \pm 0.2 \mathrm{ka}$ (Arenas et al., 2010). The latter deposits form mostly vertical, hanging structures and are encased $c a 18 \mathrm{~m}$ in the Pleistocene tufas (Fig. 7F).

Large flat areas along the upper stretch of the Añamaza valley (upstream of Salto del Cajo) are occupied by grey-coloured and beige-coloured fine sediments (Fig. 1B and C) that at present are loci for agriculture works. These Holocene 

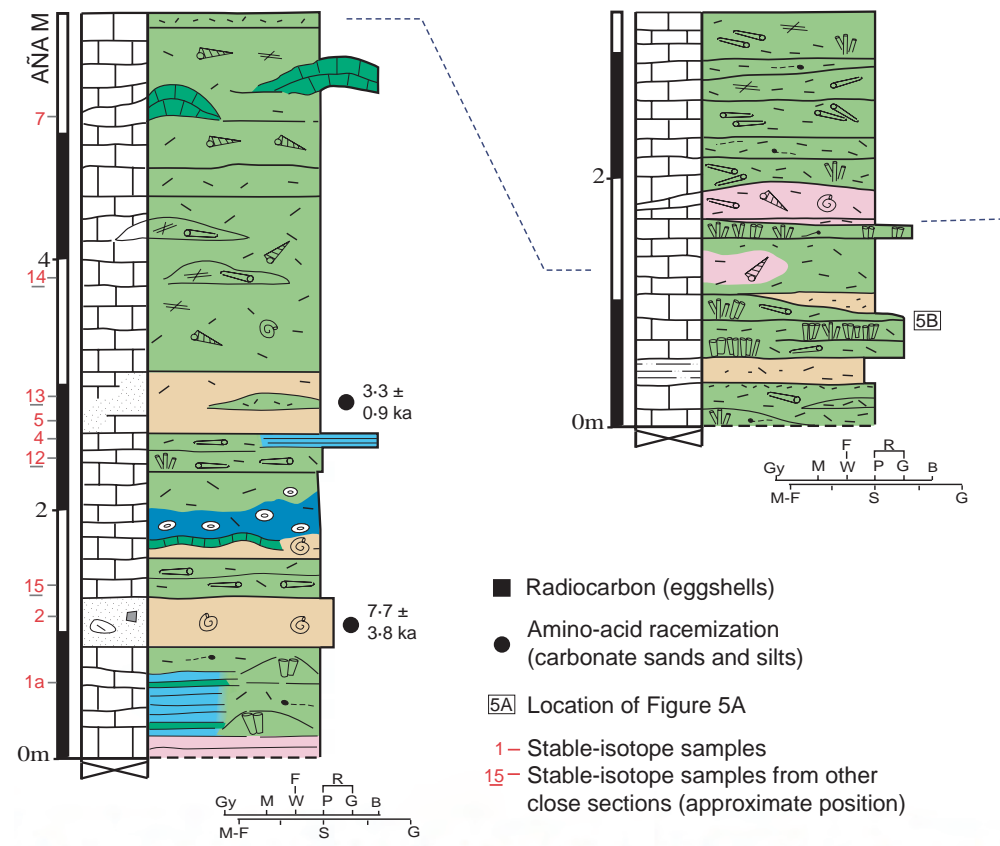

- Radiocarbon (eggshells)

Amino-acid racemization

(carbonate sands and silts)

5A Location of Figure 5A

1 - Stable-isotope samples

$1 \underline{5}$ - Stable-isotope samples from other close sections (approximate position)
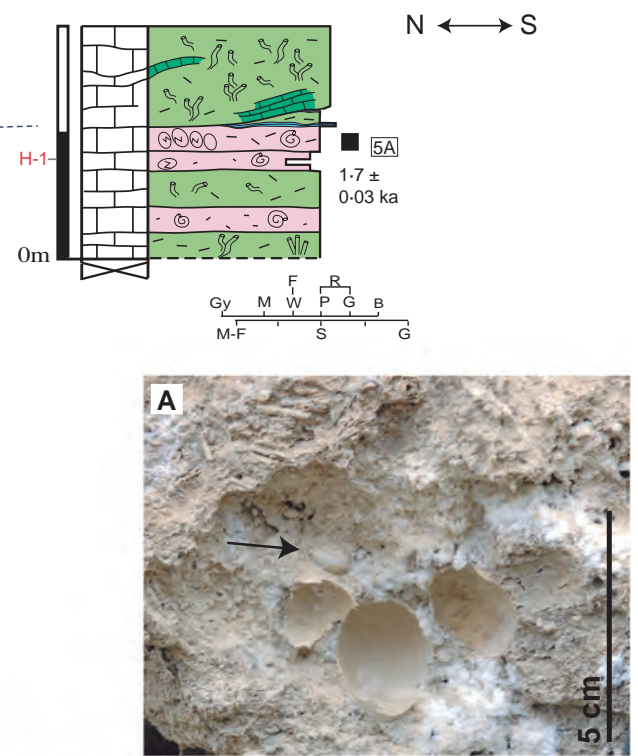
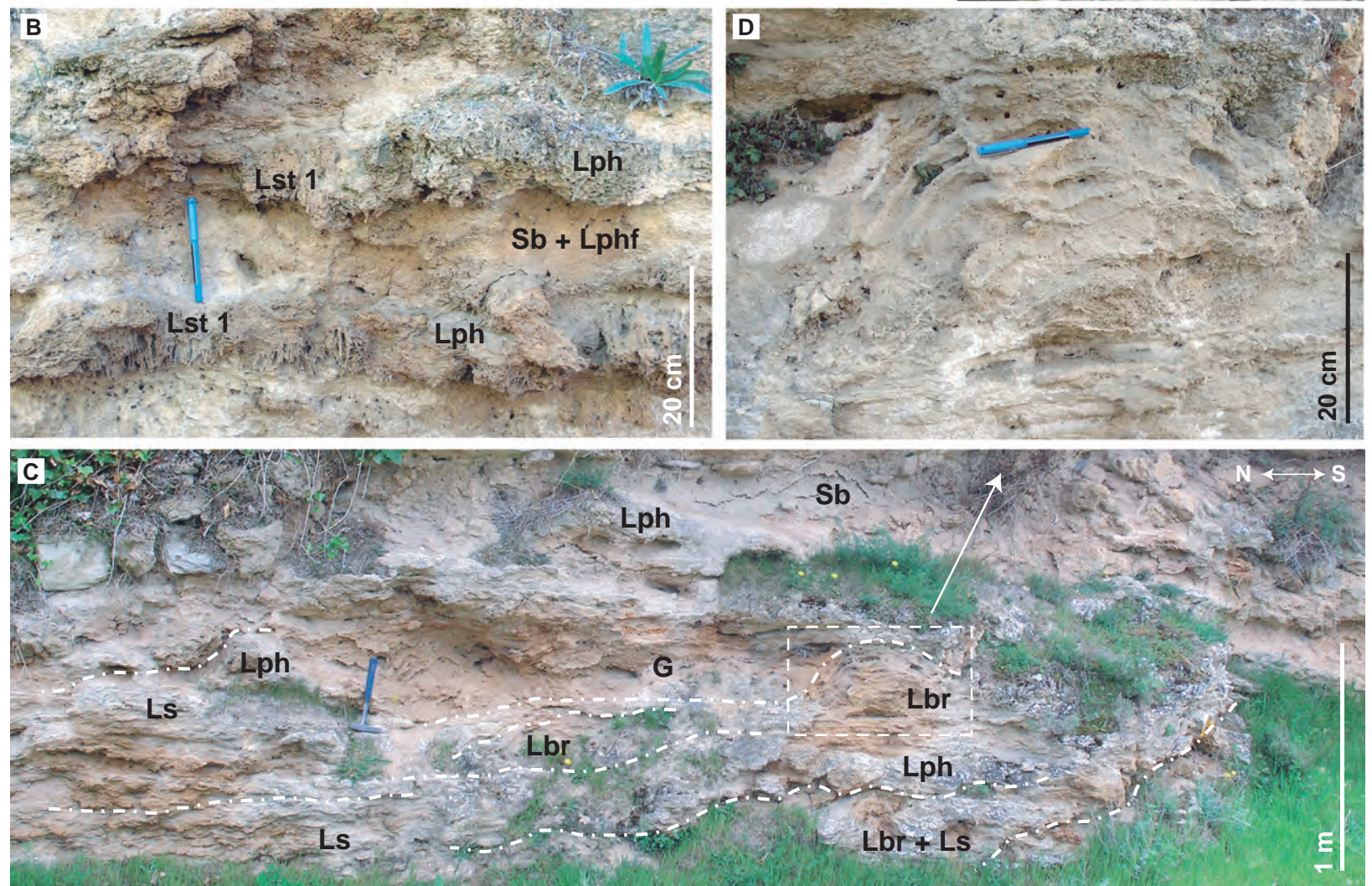

Fig. 6. El Molino Holocene site. Stratigraphical sections of the AÑA M build-up (AÑA M in Fig. 1B). Chronological data from Arenas et al. (2010). (A) and (B) Field views of section AÑA M. (A) Detail of eggshells used for dating. Note the presence of gastropods (arrowed). These components appear in fine phytoclastic and stem phytohermal tufas. (B) Alternating phytoherms of stems (Lst 1) laterally related to phytoclastic tufa (Lph) and bioclastic sands and fine phytoclastic tufas (Sb and Lphf), arranged as FA 8. (C) Field view of an Holocene deposit at the northern part of El Molino site (further north of sections), mainly made of stromatolitic (Ls) and moss (Lbr) phytoherms, along with phytoclastic tufas (Lph) and minor bioclastic sands and silts (Lb). Note the gentle slope to the north (an erosional surface on the right side) and the presence of small mounds of facies Lbr D. Legend of symbols in Fig. 2. Texture and lithology of stratigraphical sections: Gy: gypsum; M: mudstone; W: wackestone; P: packstone; G: grainstone; B: boundstone; F: floatstone; R: rudstone. M-F: marls and fines; S: sand; G: gravel.

(C) 2013 The Authors. Journal compilation (C) 2013 International Association of Sedimentologists, Sedimentology, 61, 133-171 

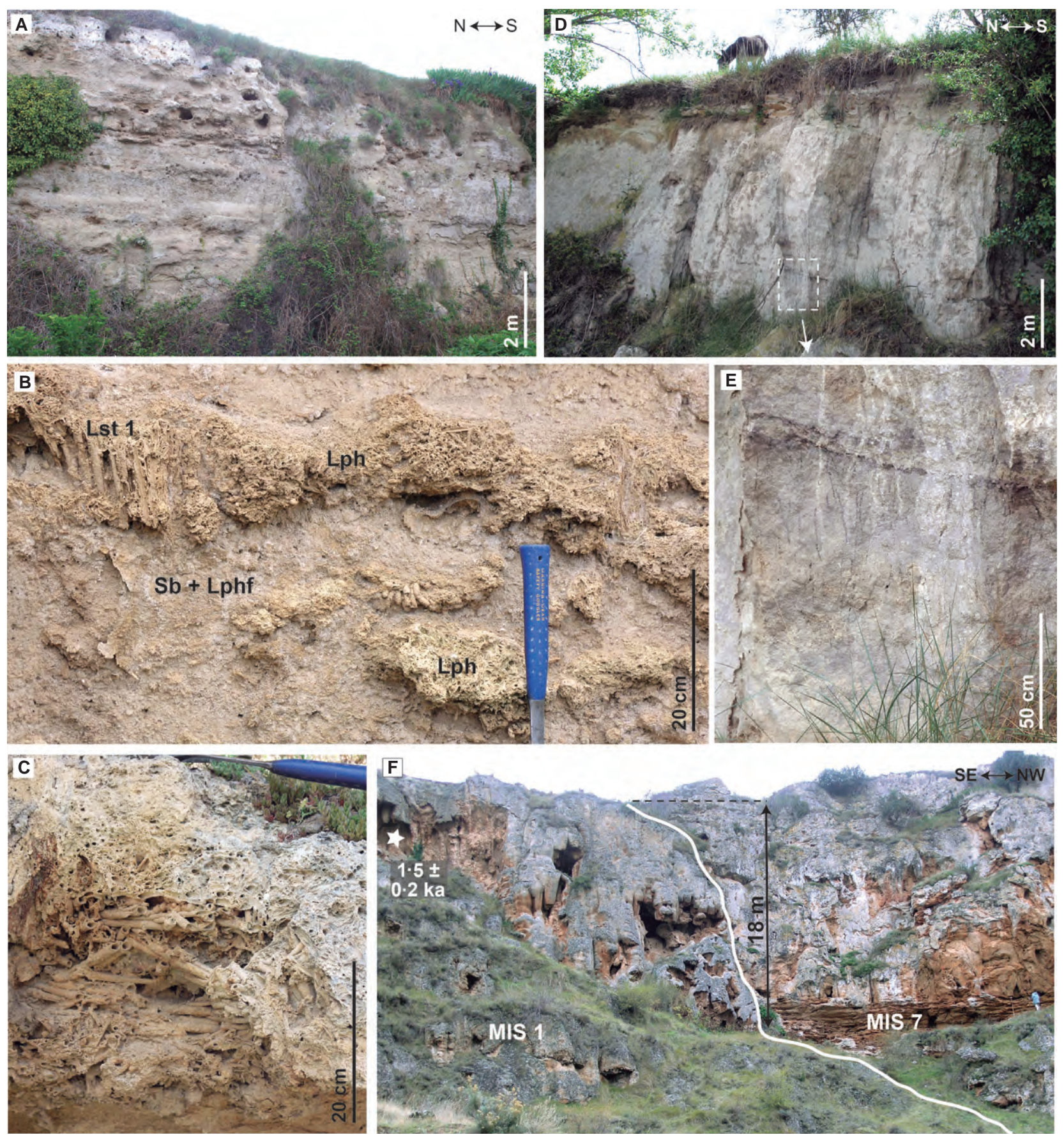

Fig. 7. Field views of the Holocene Dévanos and Salto del Cajo sites (DEV and SC in Fig. 1B). (A) Northern part of the Dévanos site: Alternating phytoclastic and phytohermal facies (Lph, Lst 1) and minor bioclastic sands and silts and fine phytoclastic tufas (Sb and Lphf). (B) Detail of the above-mentioned facies relation at the northernmost part of the outcrop. (C) Detail of phytoclastic tufas in the same bed as tufas in image (B). (D) Southern part of the Dévanos site: Light grey carbonate sands and silts with minor phytoclastic tufas. (E) Detail of (D) showing organic-matter rich laminae and root traces in carbonate sands and silts (base of FA 7). (F) The Salto del Cajo build-up: deposits of vertical cascades (MIS 1) over incised older tufa deposits (for example, MIS 7). Chronological data from Arenas et al. (2010).

sediments consist of lime mud, carbonate sands, mudstones and marls with tufa debris (millimetre to centimetre-sized fragments) and organic matter (Arenas et al., 2009; Luzón et al.,
2011). Patches of phytoherm tufas and minor coarse detrital sediments (gravels and conglomerates) are interbedded. The thickness of these Holocene deposits ranges between $3 \mathrm{~m}$ and 
$21 \mathrm{~m}$, depending on sites, as estimated from drilling logs (Luzón et al., 2008, 2011; Pérez et al., 2010). Datings obtained by the latter authors span from $10 \cdot 6$ to $0 \cdot 6 \mathrm{ka}$.

There is no sedimentary record for MISs 4 to 2. It is most likely that the dominant erosional processes during this period created a profound incision reaching the deposits of MIS 9 at the Salto del Cajo build-up. Some of the Holocene deposits were deposited over this surface (for example, the deposits of MIS 1 on deposits of MISs 7 and 5 at Salto del Cajo, Fig. 7F; deposits of MIS 1 encased in deposits of MIS 5 at El Molino, Fig. 1C).

\section{SEDIMENTOLOGY}

\section{Facies and facies associations}

Most facies present in the studied area (Table 1) have been recognized in other tufa-bearing deposits elsewhere (Ordóñez \& García del Cura, 1983; Pedley, 1990, 2009; Violante et al., 1994; Arenas et al., 2000, 2007; Capezzuoli et al., 2009; Arenas-Abad et al., 2010; Vázquez-Urbez et al., 2012). In the Añamaza valley, carbonate facies include phytoclastic tufas (Lph and Lphf), phytoherm tufas of stems (Lst 1 and Lst 2), bryophytes (Lbr) and minor charophytes (Lch), stromatolites (Ls), oncoidal limestones (Lo), bioclastic limestones (Lb), intraclastic limestones (Li), lime mud (mostly silts) and carbonate sands with bioclasts (Sb) and speleothems (Lsp). The macroscopic (Figs 2 to 7 ) and microscopic (Fig. 8) features of these facies (geometry, texture and sedimentary structures), along with their abundance and depositional environmental interpretation, are summarized in Table 1.

The most abundant facies are the phytoclastic rudstones (Lph, Fig. 8C and D) which commonly appear associated with minor boundstones of stems (Lst 1, Fig. 8A and B) forming tabular or lenticular beds that are a few centimetres to $1.5 \mathrm{~m}$ thick. For instance, this is observed in the middle part of section C-1, Salto del Cajo buildup (Fig. 3A and B), southern part of El Molino (Fig. 6B) and Dévanos sites (Fig. 7A, B and C).

Mounds of stacked layers of calcite-coated mosses (up to $7 \mathrm{~cm}$ thick; Fig. 8E and F), often with a steeply inclined structure, for example, hemi-domes up to $5 \mathrm{~m}$ high (Lbr), are conspicuous (Figs 2B, 2E, 4D, 5A and 6C). Commonly, beds of facies Lph and Lphf appear either interbedded with moss layers or at the base of the mounds (section C-1, Salto del Cajo build-up, Fig. 2E; upper part of section AÑA 13, Las Parideras site, Fig. 4B and D; El Molino site, Fig. 6C). In some cases, the moss mounds include boundstones of hanging stems, facies Lst 2 (for example, sections C-1 and C-4, Salto del Cajo build-up, Fig. 2B; upper part of section AÑ 13, Las Parideras, Fig. 4B and C). In other areas, deposition occurred as successive low-angle wedges (as in the case of the middle part of section C-2, Salto del Cajo build-up; Fig. 2E) and gently inclined lenticular beds (for example, the northernmost part of the El Molino site; Fig. 6C) of phytoclast (Lph) and intercalated moss (Lbr) facies.

Stromatolites (Ls; Fig. 8G to K) stand out because of their abundance and the geometry of their deposits; they constitute gently to steeply inclined, tabular and lenticular strata, at places forming small domes, centimetres to $1 \mathrm{~m}$ thick; although exceptions may exist, the gently inclined ones commonly appear over facies Lph and Lst 1, whereas the steeply inclined ones are usually interbedded with steep moss layers (Lbr) (for instance, between surfaces S3 and S4 in section C-1, Salto del Cajo build-up, Fig. 3C to E). In the northernmost part of the El Molino site (Fig. 6C), discrete moss mounds (Lbr) and laminated facies (Ls) developed.

Carbonate sands and silts (facies Sb, Fig. 8L) form tabular and lenticular bodies, up to $0.5 \mathrm{~m}$ thick, although these are grouped in thicker sets, which commonly display lamination and/or layering (for example, lower half of section AÑ 13, Las Parideras site, Fig. 4B and D; AÑA 7N section, Fig. 5A and D). Facies Sb is particularly thick and extensive in the southern part of Dévanos site (Fig. 7D and E). These loose sediments can include thin beds of bioclastic, intraclastic and phytoclastic limestones (Lb, Li, Lph and Lphf; for instance, Las Parideras site, Fig. 4C and D) and appear laterally and vertically related to facies Lbr and Lst 1 (for example, El Molino site, Fig. 6B and C; Dévanos site, Fig. 7B). In the Las Parideras site, a succession of banded and laminated bioclastic sands and limestones (Sb, $\mathrm{Lb}$ and Lphf), with minor layers of mosses (Lbr) and of intraclastic limestones (Li) pass into the inclined layers of mosses and phytoclasts of downstream and upstream mounds (Fig. 4C and D). Although uncommon, small phytoherms of charophytes (facies Lch) occur associated with facies $\mathrm{Sb}$ (top of section C-2, Salto del Cajo build-up, Figs 2B and 3F).

Facies Lb and Li (Figs 8M and 4E) commonly form tabular deposits up to $1 \mathrm{~m}$ thick with 


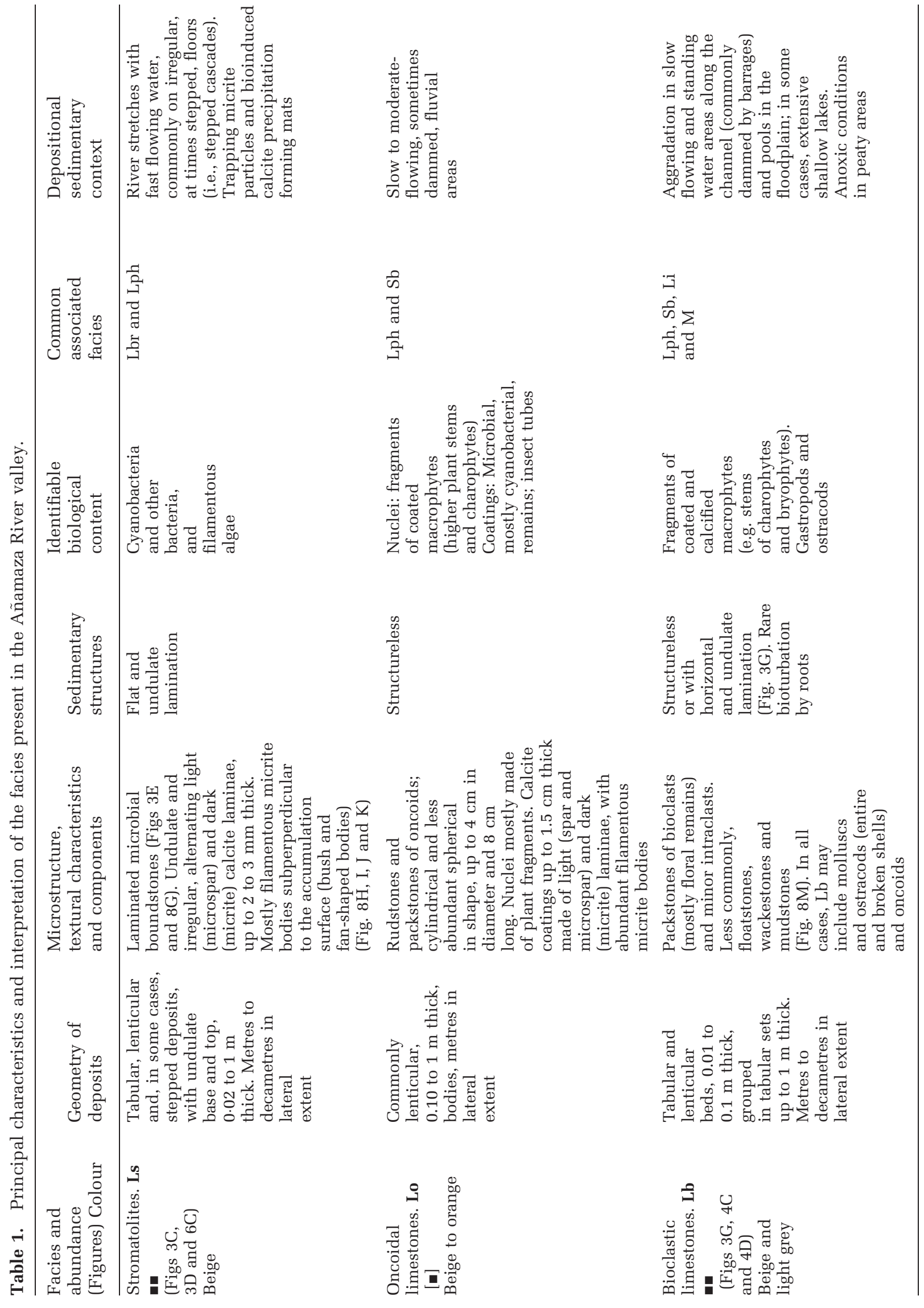




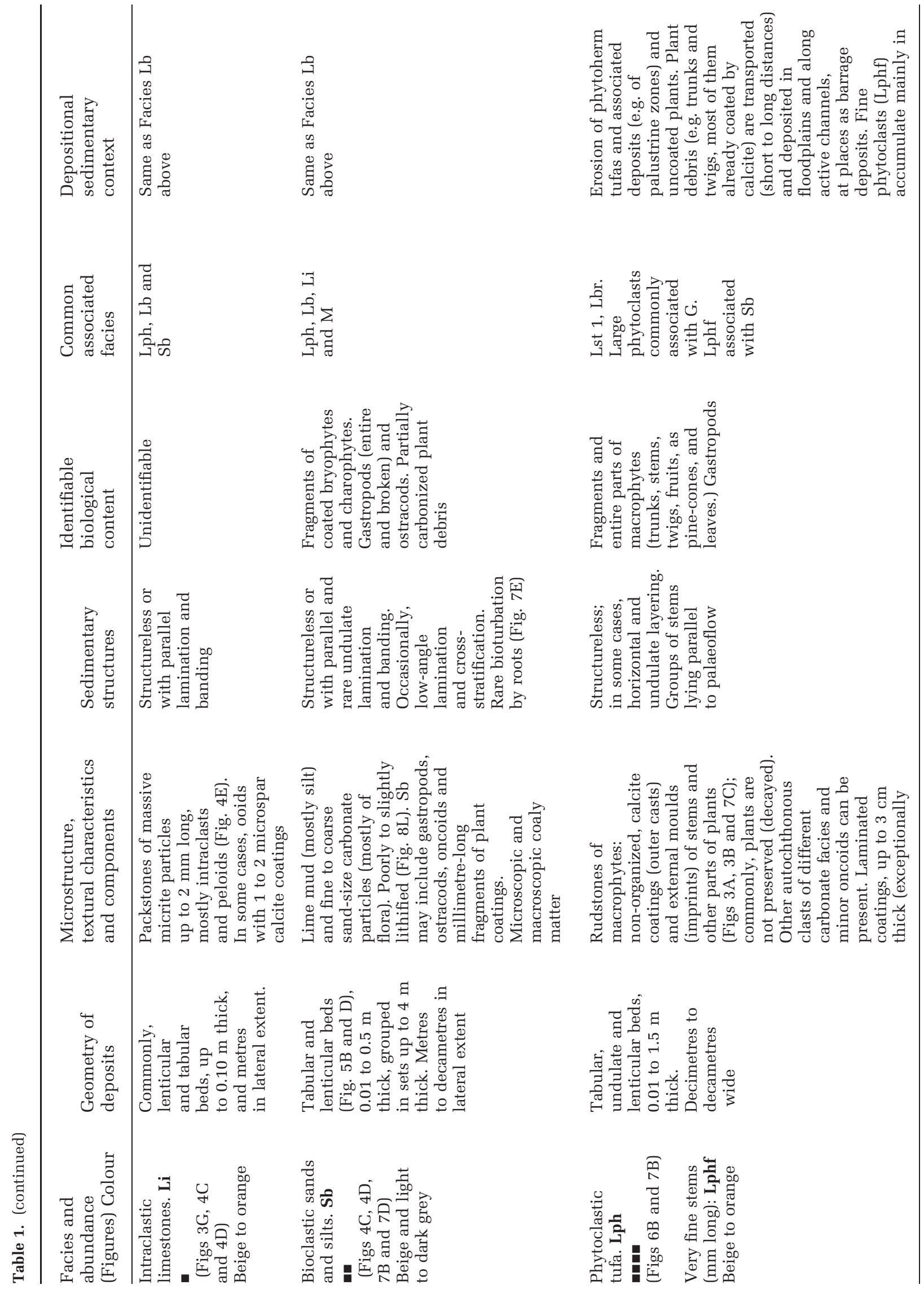




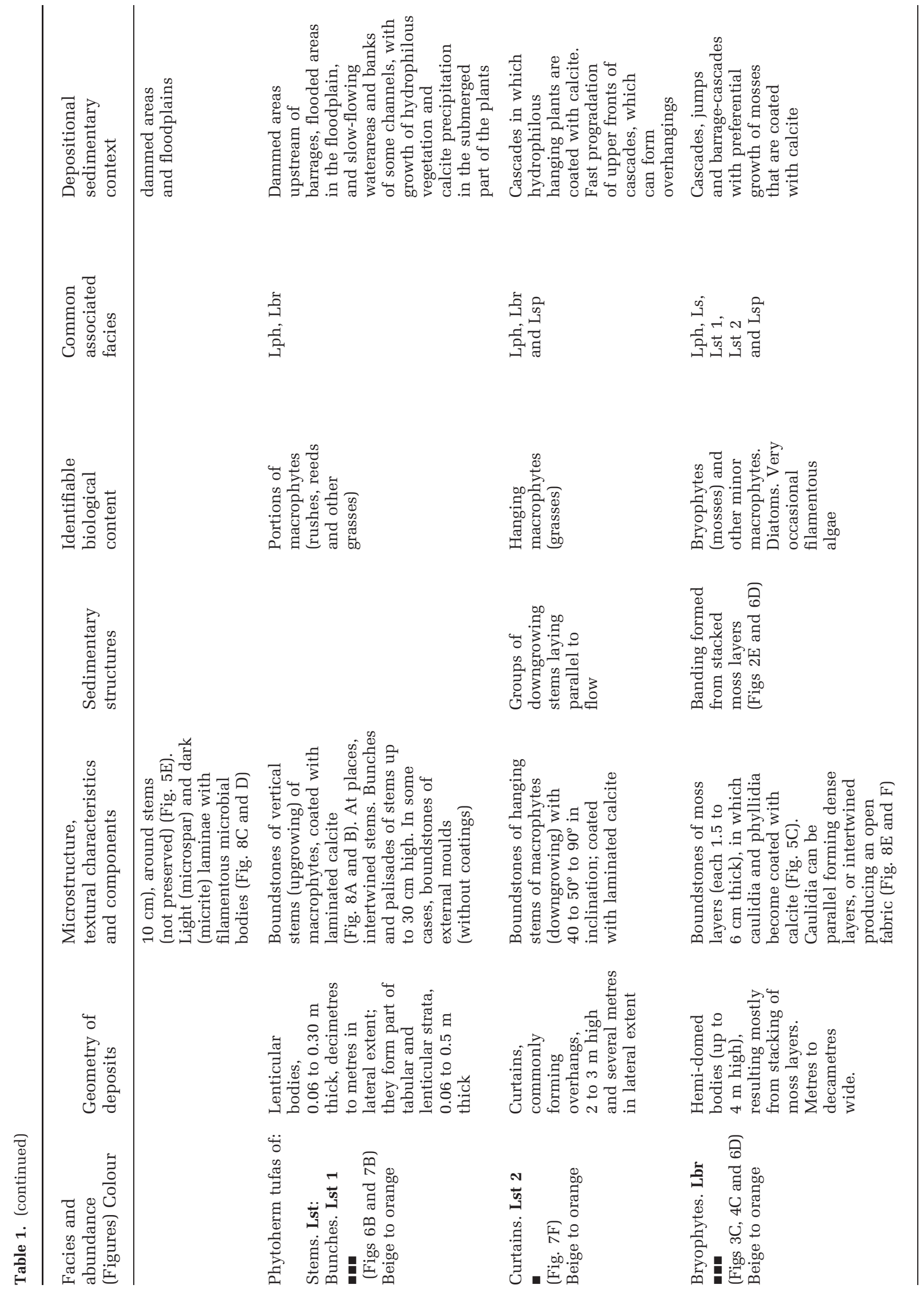

(C) 2013 The Authors. Journal compilation (C) 2013 International Association of Sedimentologists, Sedimentology, 61, 133-171 


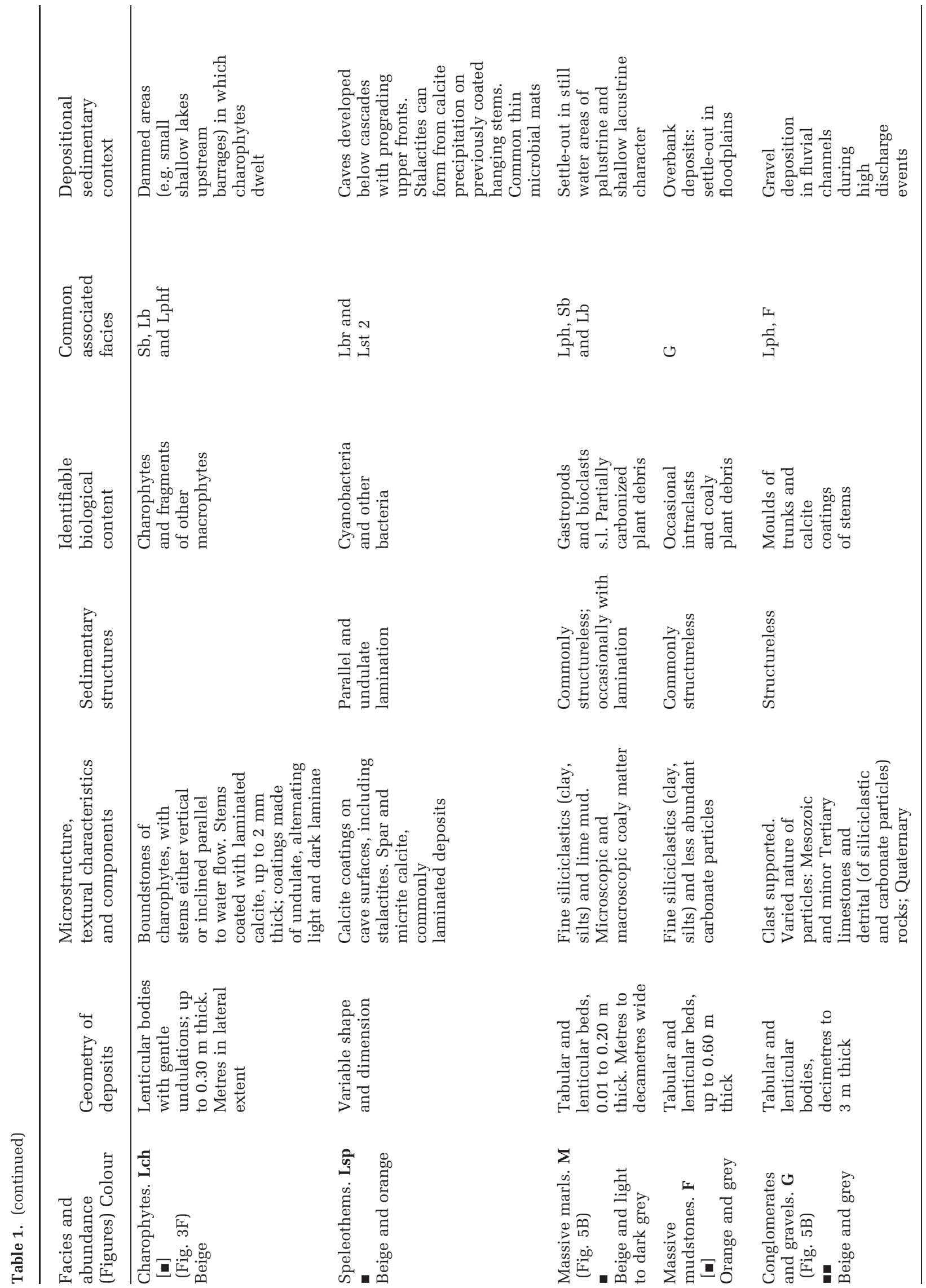

(C) 2013 The Authors. Journal compilation (C) 2013 International Association of Sedimentologists, Sedimentology, 61, 133-171 


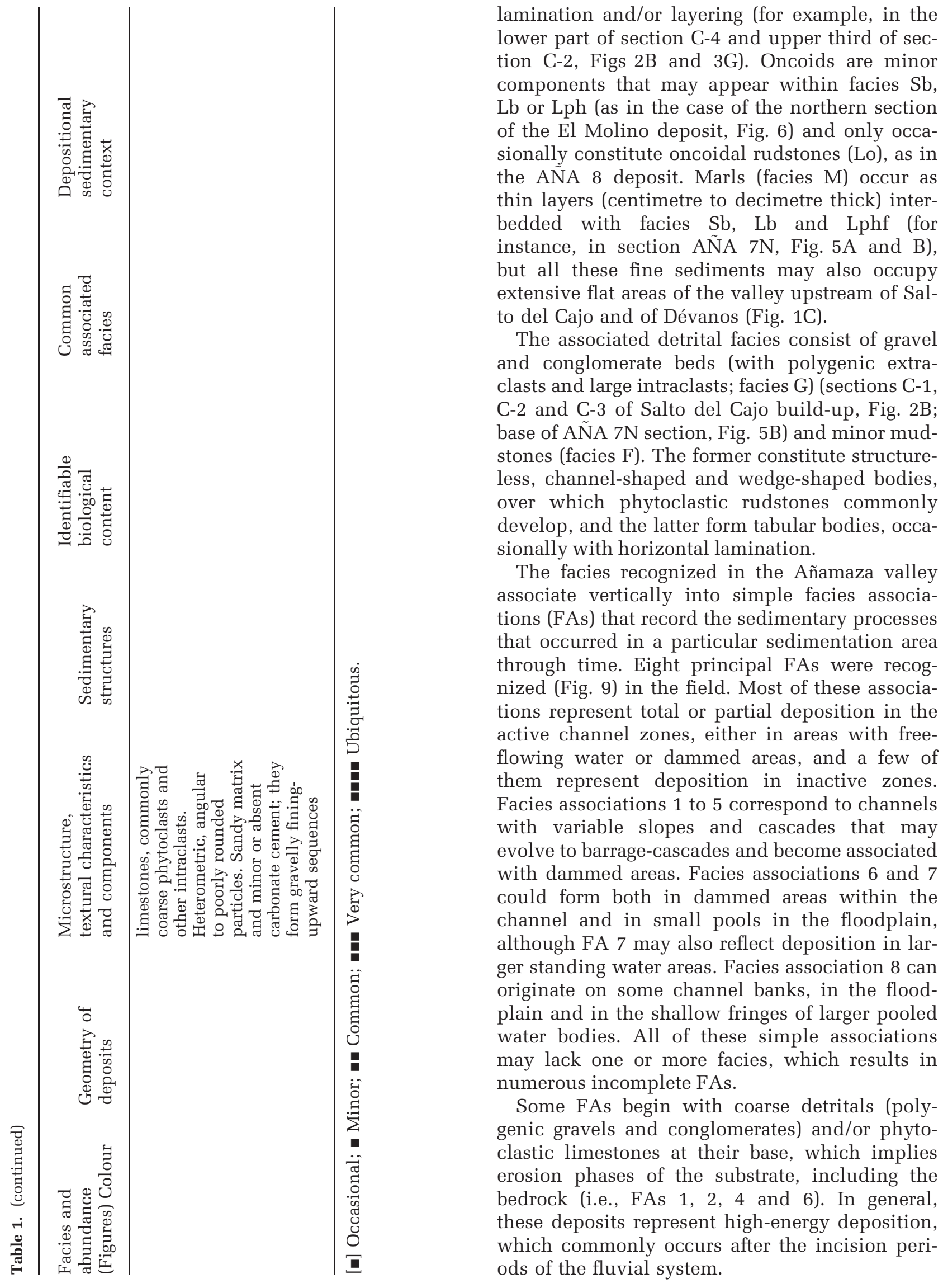



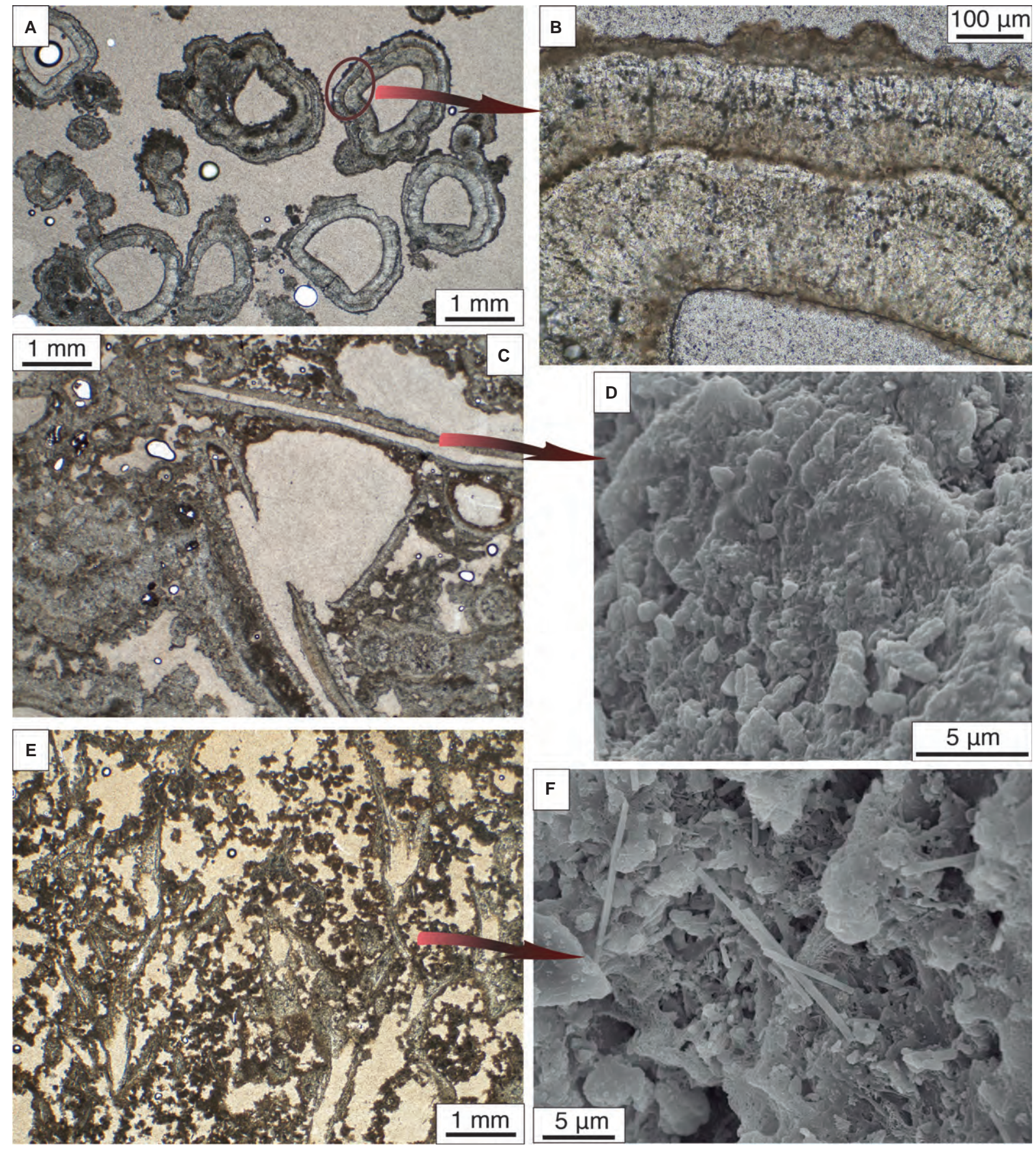

Fig. 8. Photomicrographs of tufa and associated facies. (A) Cross-sections of laminated coatings of stems in a boundstone of stems (facies Lst 1). (B) Detail of a coating, showing two micrite-microspar laminated intervals. Note the presence of upright filamentous bodies and clotted texture. (C) Phytoclastic tufa (rudstone, facies Lphf) made of cross and parallel sections of stems coated by micrite and microspar calcite. Note the clotted or peloidal matrix. (D) Calcite crystals in a stem coating of image (C), showing abundant microbial bodies on and among them. (E) Boundstone of mosses (facies Lbr). (F) Detail of calcite crystals of a phyllidium coating, including microbial bodies (strait crystals are needle-fibre calcite). (G) Stromatolite consisting of successive intervals made of adjacent bush-shaped bodies separated by microspar calcite laminae (facies Ls). (H) Detail of bush-shaped bodies of (G) showing upright calcite tubes that represent the coatings around cyanobacteria or algae. (I) Detail of (H). (J) Fan-shaped body in a stromatolite. (K) Detail of a tube-like body in (J). Note the much smaller central void that corresponds to the cyanobacterium that acted as a template for calcite precipitation and the thicker calcite coating, compared to the tube-like body in (I). (L) Slightly lithified bioclastic silt (facies Sb), showing mostly floral components. (M) Packstone of bioclasts (floral components) and intraclasts with ostracods (arrowed) and small oncoids (facies Lb). 

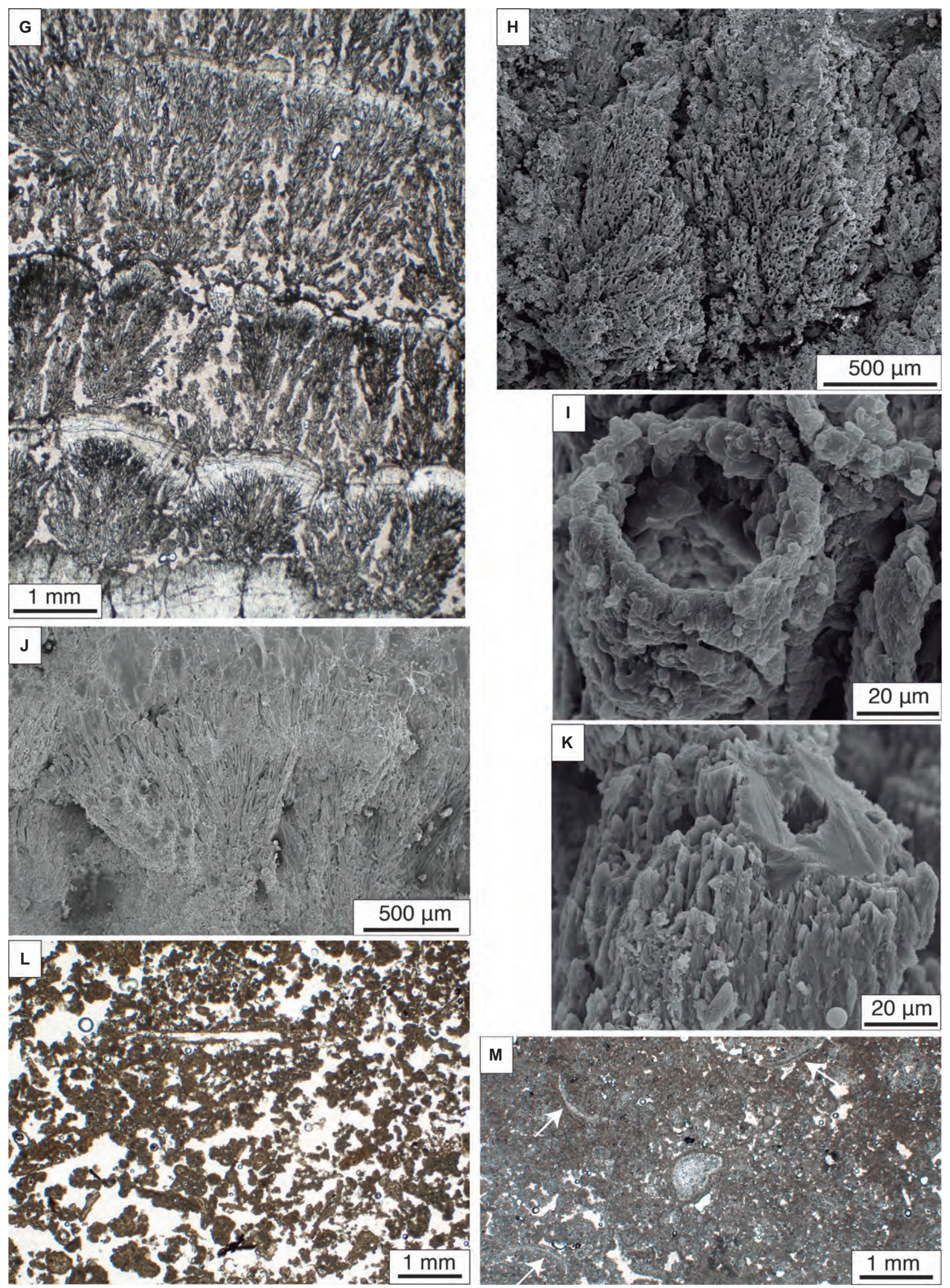

Fig. 8. Continued. 
Facies association 1: Steep channel

Facies association 1 represents the deposition of tufa on a highly sloped channel area after erosion and the subsequent sedimentation of coarse gravels. The erosion of upstream vegetated areas with calcite-coated plants produces phytoclasts that are deposited as several wedge-shaped bodies of facies Lph. These phytoclasts may alternate with discrete layers of facies Lbr that formed in less energetic conditions; moss mounds would be built in some places (for example, small jumps, generally $<1 \mathrm{~m}$ high, along the river) producing a gentle stepped profile, although without development of barrages that could dam water due to the high slope. Facies association 1 has been recognized in the Salto del Cajo area (section C-2 in Fig. 2B; Fig. 2C and D).

\section{Facies association 2: Stepped cascade}

Facies association 2 formed after the strong initial erosion and deposition of coarse gravels (facies $\mathrm{G}$ ) and phytoclastic sediments (facies Lph) along the river bed. Similar to FA 1, FA 2 represents deposition over a steep channel area, but with a highly irregular bottom that consists of several steps that would mostly constitute a stepped cascade (i.e., a non-vertical, convex-shaped cascade). Mounds of stacked layers of mosses (facies Lbr) would form in areas of mild water flow and splash, whereas stromatolites (facies Ls) would form in areas of faster water flow. Local changes in flow conditions would give rise to the alternation of these two facies which, in some cases, would imply the erosion of facies Lbr. This FA can be observed at the northern part of the Salto del Cajo area (section C-1 in Fig. 2B; Fig. 3C and D).

\section{Facies association 3: Low-slope channel with pools}

Facies association 3 records deposition in the gently to slightly moderate sloped channel areas where abundant hydrophilous plants could dwell in shallow conditions, giving rise to facies Lst 1. As a result of breakage during phases of water flow with slightly increasing energy, phytoclasts would accumulate (Lph) in nearby areas. Microbial mats and moss layers would cover such phytoherm deposits, forming small domes of facies Ls and Lbr, which in some cases could evolve to larger moss domes that would eventually hold back water. In these standing to slow-flowing water pools, sedimentation would consist of carbonate sands (Sb), phytoclasts (primarily Lphf) and minor oncoids (Lo). The growth of plants, moss and microbial deposits and deposition in small pooling areas would lead to the filling of the gently to moderately sloped parts of the river, primarily through aggradation; however, the process could be interrupted by new phases of increasing energy that would partially erode the previous deposits. This FA has been recognized in the El Molino sector (Fig. 6C and D).

\section{Facies association 4: Barrage-cascade and dammed areas}

Facies association 4 illustrates the deposits resulting from creation of a barrage-cascade, which became a dam that would hold water back in small to large areas. This process has been described in other stepped fluvial systems (Vázquez-Urbez, 2008; Pedley, 2009; ArenasAbad et al., 2010; Vázquez-Urbez et al., 2012). Briefly, the FA represents the massive filling of a channel with coarse detrital sediments, including phytoclasts (facies G). The accumulation of diverse sizes of phytoclasts (calcite-coated and uncoated parts of plants), sometimes trunks, would create irregularities in the channel and, in places, small barrages. These areas would be propitious for the growth of bryophytes. The progressive accumulation of moss layers (Lbr) would create mounds that might have grown to produce cascades, which commonly would evolve to form larger barrages. The fast progradation of the cascade front would produce overhangs from hanging plants (facies Lst 2) under which caves would be created; in this context, the speleothemic facies would form (Lsp). Upstream of the barrages, in the pooling areas, fine bioclastic sediment and lime mud would accumulate, along with skeletons of molluscs and other aquatic organisms (facies Sb, Lphf and Lb). Millimetric intraclasts would also form producing facies $\mathrm{Li}$, along with peloids and ooids. Up-growing charophytes would only be preserved in quiet conditions; commonly, these calcified algae are observed as fine particles within facies $\mathrm{Sb}$ and Lb. Hydrophylous plants would often colonize the shallow margins of the dammed areas. In some stagnant water bodies, the accumulation of microscopic and macroscopic organic matter may produce peat-rich layers. This FA has been recognized, although mostly incomplete, in the upper part of Salto del Cajo (C-1 in Fig. 2B), AÑA 7N (Fig. 5A), AÑA 8 and upstream of AÑA 13.

\section{Facies association 5: Cascade and dammed areas \\ This FA represents the deposits resulting from progradation of a cascade over a dammed area.}


Facies association 5 records the progressive stacking of moss layers (Lbr) at the edge of a pooled area, mostly through progradation, which would give rise to a build-up that laterally changes into the deposits of a downstream area of pooled water. Bioclastic, fine phytoclastic and intraclastic sediments would accumulate in this area, in some cases with crude lamination and banding. The latter area may correspond to both small pools along a gentle stepped channel and to a larger dammed area (facies Sb, Lb, Li and Lphf). In any case, the structure implies a dominant progradation process. This FA has been observed in the area of Las Parideras (AÑA 13 in Fig. 4).

\section{Facies association 6: Pools in the channel and floodplain}

This association was produced in narrow flat areas of the valley, where pools were created after the initial filling of the channel with coarse detrital sediments $(\mathrm{G})$ and phytoclasts (Lph) from nearby vegetated areas. These pools might also correspond to abandoned channel stretches. The deposition in the pools would record intermittent supplies of water and sediment, firstly with the deposition of bioclastic facies (Sb) following floodings and then with the settling of lime mud and marls in waning water flow conditions. This FA has been recognized at the northern part of the valley (for example, section AÑA 7N, Fig. 5B).

Facies association 7: Shallow lakes and pools This FA was formed by deposition in shallow lakes or ponds that were subject to variable supplies of water and sediment. Thick sedimentation of bioclastic sands and silts (Sb) would occur as a result of significant water input that would carry carbonate particles (generated from the breakage of upstream tufa and associated deposits). Root traces account for the shallow conditions and organic matter preservation for anoxic conditions, perhaps in deeper water. The organic matter might have formed and accumulated in such areas, thereby producing sapropelic layers. Episodic, larger water inputs, which were most likely associated with wetter conditions, would carry phytoclasts from the erosion of palustrine or densely vegetated areas upstream (deposited as layers of Lph and Lphf) and clays from distal alluvial deposits. Marls represent settling in calm conditions after such water inputs. Facies association 7 has been recognized close to the village of Dévanos (Fig. 7D and E) and is also inferred from logs retrieved by Luzón et al. (2011).
Facies association 8: Palustrine zones

This FA records small fluctuations in the water levels in shallow areas with a generally dense cover of hydrophilous vegetation, both on lake shores and in pools along the channels. Plants living in those areas, whose submerged parts would be coated by calcite, would be liable to breakage by currents. Their fragments (calcitecoated and uncoated parts of plants) would accumulate in nearby areas as facies Lph; minor oncoids could also be formed from such fragments (Lo). These marshy areas may be flooded as a result of increasing water inputs (for example, during periods of higher precipitation) and/or increased aggradation of a downstream barrage. The resulting sedimentation would correspond to facies $\mathrm{Sb}$, Lphf and $\mathrm{Lb}$. In some cases, in anoxic conditions, organic matter would be preserved as peat-rich layers within bioclastic sediments. This facies succession can be observed near the village of Dévanos (Fig. 7A to C) and in the El Molino outcrop (AÑA M; Fig. 6B).

\section{Sedimentological characterization of the Pleistocene deposits}

Salto del Cajo (SC in Fig. 1B; Figs 2 and 3). This tufa build-up is composed of several lenticular shaped and wedge-shaped bodies that are $c a 10$ to $35 \mathrm{~m}$ thick and dip northwards. These bodies record deposition over extensive, steep-sloped, stepped and irregular erosional surfaces (for example, S1 to S4) where gravels (containing extraclasts and intraclasts, primarily phytoclasts) were laid as the first channel fill deposits (Fig. 2A and B). In some areas (for example, the middle part of section C-2), deposition occurred as successive low-angle wedges of phytoclast (Lph) and intercalated moss (Lbr) facies, with facies $G$ at their base (FA 1; Figs 9, 2C and D). Facies Lbr and Ls constitute hemi-domed and highly inclined deposits that formed in reaches of medium to high slope, i.e., stepped cascades and some steep stretches with fast-flowing water (FA 2; Fig. 3C and D). These cascades mostly developed from a basal accumulation of gravels and phytoclasts. Alternating Lbr and Ls facies (for example, between surfaces S3 and S4 in section C-1) provide evidence of changing energy conditions in laterally related, high gradient environments (FA 2). The stepped cascades evolved over time into vertical waterfalls and cascade-barrage systems, mostly composed of facies Lbr and the associated Lst 2. Some caves 
Free-flowing water areas

Low-slope channel with pools

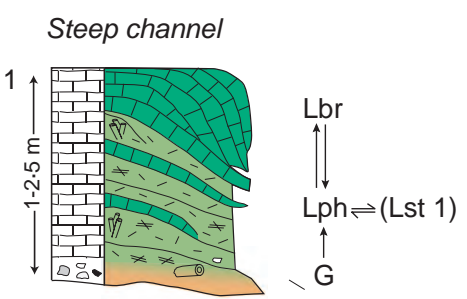

Stepped cascade

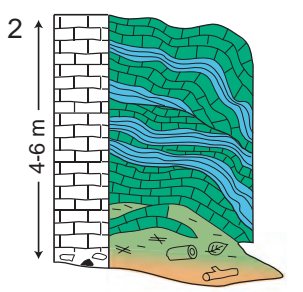

LS
$\uparrow \downarrow$
Lbr
$\uparrow$
Lph
$\uparrow$
$(G)$
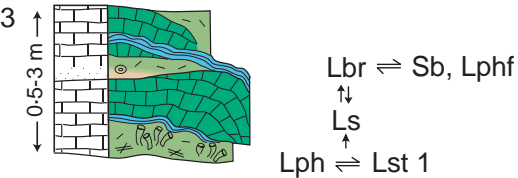

Barrage-cascade $\rightarrow$ Dammed areas

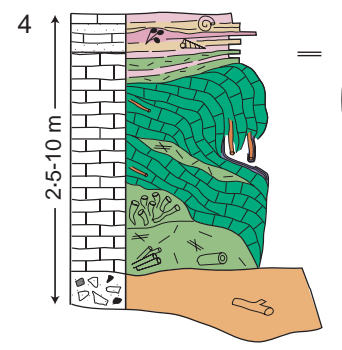

Cascade and dammed areas

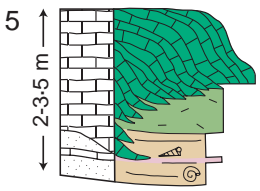

Lb
Pools and

dammed areas

Pools in the channel and floodplain

6

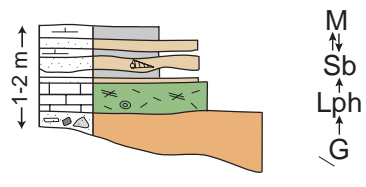

Shallow lakes and pools

7

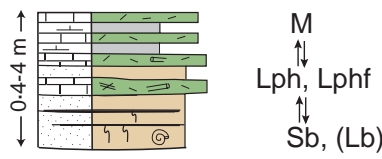

\Erosional base $\quad \uparrow$ Vertical passage

$\uparrow$ Alternating facies

$\rightleftharpoons$ Lateral passage

( ) Occasional facies, Alternative or coexisting facies

Fig. 9. Facies associations (FAs) representative of the different environments present in the Añamaza River valley. Legend of symbols in Fig. 2.

may have arisen from the progradation of the latter two (for example, FA 4). The steep slope of the river in this part of the valley restricted the development of dammed areas in the channel to moments with great barrage-cascade growth (for example, upper part of section C-1; FA 4). Therefore, the facies $\mathrm{Sb}, \mathrm{Li}$ and $\mathrm{Lb}$ formed in pools upstream of these barrage-cascades are not abundant, nor extensive in this part (for example, in the lower part of section C4, Fig. 3G, and upper third of section C-2). The phytoherms of charophytes (Lch) and marls (M) are considerably less abundant. At the same time, the steep slope hindered the development of a floodplain and favoured the erosional processes, which explains the rarity of palustrine facies (for example, FA 8) and the common presence of gravel and phytoclast deposits.

Although the general water flow and tufa growth were towards the north, changes in the main direction close to $90^{\circ}$ can be deduced from the several depositional stages recorded in the Salto del Cajo build-up. These changes in the flow direction were produced after erosion of some parts of the valley, which increased the accommodation space and the consequent migration of the main channel. Thus, this was a steep part of the valley broad enough $(\approx 0.3 \mathrm{~km})$ to allow wide variations of the main channel direction.

Las Parideras (AÑA 13 in Fig. 1B; Fig. 4). An extensive tufa deposit appears in the Las Parideras sector, although its outcrop is not fully continuous, but rather composed of partially disconnected, laterally correlatable bodies. Figure 4 shows the upper part of the easternmost wedgeshaped tufa body. At the base, the tufa deposit consists of small mounds of facies Lbr developed over phytoherms of stems (Lst 1) and phytoclastic tufas (Lph). The mounds of facies Lbr pass downstream into a succession of banded and laminated deposits of facies $\mathrm{Sb}, \mathrm{Lb}$ and $\mathrm{Lphf}$, with minor layers of facies Lbr and of intraclastic limestones (Li), which represent the deposits of small dammed areas (Fig. 4C to E). In turn, the dammed deposits pass into the inclined layers of facies Lbr and Lph of a downstream mound. This arrangement evokes a gentle, stepped river course with very small pooled areas. Later progradation of larger moss mounds produced larger cascade structures, in places developed from or including phytoclast accumulations (conforming 
to, FA 5; Fig. 9). In some cases, these structures included hanging stems (Lst 2). The progradation eventually gave rise to small caves behind the waterfalls. This arrangement of facies conforms to FA 4 (Fig. 9). Downstream of the upper cascade structure, banded deposits (Lph-rudstones, and coarse Sb), which are not shown in Fig. 4C, were deposited in dammed areas of unknown extent (due to erosion). The uppermost deposit in this build-up is a phytoclast rudstone (Fig. 4B) that represents erosion and the beginning of another depositional stage.

Other Pleistocene build-ups (for example, AÑA 7, Fig. 5; and AÑA 8) resulted from deposition conforming to FAs 4, 5 and 6 . These data suggest the existence of barrage-cascade deposits and small dammed areas in the northern studied area.

\section{Sedimentological characterization of the Holocene deposits}

El Molino (AÑA $\mathrm{M}$ in Fig. 1B; Fig. 6). In the northern part of the El Molino deposit (thicker section in Fig. 6), discrete mounds of facies Lbr and thin layers of facies Ls developed. Phytoclastic rudstones (Lph) and grey coarse sands (Sb), including gastropods, some oncoids and intraclasts, deposited in dammed, slow-flowing water areas. Together, this provides evidence of a channel with small mounds of mosses (up to $1.5 \mathrm{~m}$ high) and pools (for example, FA 3; Fig. 9). In the southern part (thinner sections in Fig. 6), abundant boundstones of stems (Lst 1) and rudstones of phytoclasts are associated with bioclastic and intraclastic limestones and sands (Lb, Li and Sb; Fig. 6B). Eggshells $(\approx 2$ to $3 \mathrm{~cm}$ long) of small birds were found within deposits of facies Lph and coarse Sb (Fig. 6A). All of these deposits formed in palustrine areas close to shallow pools in a gentle sloped stretch of the river (as represented by FA 8). Further north of the sections (Fig. 6C), deposits of facies Lbr, Ls, Lph and Sb occur over a slightly inclined erosional surface and account for a gently sloped river course. It can be concluded that this sector of the valley corresponded to a river stretch with a gentle stepped profile that evolved over time to predominantly palustrine conditions, better developed to the south. Human actions (Roman Age and later water management) may have contributed to the final morphology and depositional pattern of this part of the valley.

Salto del Cajo waterfall (eastern part of SC in Fig. 1B; Fig. 7F). Facing north, this part of the valley presents a curtain-like tufa deposit (mini- mum $18 \mathrm{~m}$ high and $c a 0.1 \mathrm{~km}$ wide) composed of several column-shaped units of varied morphology (reverse pyramids and cones) separated by chutes (Fig. 7F). At least two stepped depositional units are observed. These units consist of phytoherms of hanging stems (Lst 2) and of highly inclined moss layers (Lbr) that enclose caves. In general, the deposit fits the overhanging part of FA 4 (without the dammed deposits) because it formed in a vertical cascade (waterfall). This deposit looks like some cascades described by Viles et al. (2007) in Namibia.

Dévanos (DEV in Fig. 1B; Fig. 7A to E). This part of the valley is distinctive due to the abundance of tabular subhorizontal to horizontal beds composed of facies Lph and Lst 1. Thin layers of bioclastic silts and sands (Sb) and fine phytoclastic tufas (Lphf) appear interbedded among the former (Fig. 7A and B), which conforms to FA 8 (Fig. 9). To the southern part of this outcrop, the deposits with facies Lst 1 are thinner and less abundant, whereas those with facies Sb increase in thickness, include peaty layers and become dominant over facies Lst 1 and Lph (base of FA 7; Fig. 7D and E). In general, this arrangement indicates that this part of the valley recorded deposition in almost flat areas with hydrophilous vegetation and pools fed during overflowing of channels or rising lake levels. This part of the valley was most probably a shallow palustrine fringe related to a larger standing water area that extended southward.

The fine-grained sediments (facies $\mathrm{Sb}$, Lphf and $\mathrm{M}$ ) that occupy extensive flat areas of the valley (for example, upstream of Salto del Cajo, El Molino and Dévanos; Fig. 1B and C) represent deposition in large pools and shallow lakes (FA 7) with extensive palustrine fringes (FA 8). The thick deposits of facies Sb, Lph, Lphf and M (stacked FA 7) recognized in these areas (i.e., 8 to $10 \mathrm{~m}$ at the outcrop of Dévanos; up to $21 \mathrm{~m}$ to the south-west of Dévanos, after drillings of Luzón et al., 2011) imply long periods of aggrading deposition in extensive lacustrine areas, which is related to the existence of persistent barrage structures downstream. The vertical growth of the barrages would balance the fill of the lacustrine areas in shallow conditions.

\section{Sedimentary facies models}

The Quaternary deposits of the Añamaza valley formed in a stepped fluvial system with cascade structures, which in many cases were barragecascades, and slow-flowing and standing water 
areas of variable extent in which palustrine zones could occur. Channel reaches with gentle slopes and small jumps also existed. To some extent, this depositional arrangement is similar to the sedimentary facies model described for other stepped fluvial tufa systems (e.g. Pedley, 2009; Vázquez-Urbez et al., 2012). However, some particular features of the Quaternary Añamaza tufas and associated facies make their depositional context distinct and allow the construction of two characteristic, conceptual models of tufa deposition. The slope of the sedimentary area along the valley is one of the primary features of these tufas, which provides a clear separation between a moderately sloped stretch and a highly sloped stretch (Fig. 10A and $\mathrm{B})$. This feature determined the distribution and extent of the different environments through space (Fig. 10C and D). Presently, the slope of the Añamaza River upstream of AÑA $M$ is $c a$ $2.5 \%$ for a stretch that is $c a 2 \mathrm{~km}$ long; it diminishes if a longer upstream distance is considered, i.e., $c a 1.3 \%$ for $c a \quad 4 \mathrm{~km}$ long. Downstream of AÑ M, the slope is larger: $c a$ $5.7 \%$ for a stretch $\mathrm{Ca} 4 \mathrm{~km}$ long that is devoid of large vertical falls, as shown in Fig. 10A and B. Similar slope values are obtained if calculations are performed for the base or top of the tufa depositional units. Therefore, parallel variations in the slope are inferred through the Quaternary.

These slope values compare well with other stepped fluvial systems, in which the mean slope varies between $2 \%$ and $3 \%$; although short reaches ( 0.5 to $0.8 \mathrm{~km}$ long) of up to $11 \%$ can occur, which are generally associated with vertical falls, as in the case of the Brandfontain (Namibia; Viles et al., 2007) and Piedra (Spain; Vázquez-Urbez et al., 2012) Rivers. However, in the Añamaza valley, large vertical topographical breaks were not common. Actually, another outstanding feature of this fluvial tufa system is the existence of extensive, non-vertical, steep reaches within the highly sloped stretch.

In general, both models (Fig. 10C and D) share most parts of the sedimentary system (channels, cascades, barrage-cascades and standing water areas), but the different slope controls their distribution and extent, as well as the development of some distinctive environments (for example, steep-channel and stepped cascade, within the steep-slope stretch). In both models, cascade and barrage-cascade structures (FAs 4 and 5) developed in knickpoints (i.e., reaches of steep slope along the longitudinal profile), which in most cases coincided with narrower reaches of the valley, in relation to variations of bedrock resistance to erosion. Later growth of these tufa buildups would have exaggerated the initial topography (D'Argenio \& Ferreri, 1988; Sancho et al., 1997). Between these build-ups, the dammed areas provided sites for the deposition of fine carbonate sediment (Sb, Lb and Lphf) and marls (M) (FAs 4 to 7). In channel reaches with gentle to moderate slopes, stromatolites (Ls), discrete domes of facies Lbr and phytoclastic tufa (Lph) formed (for example, FA 3). In some of these lowinclined parts of the valley, still and slow-flowing water areas (for example, pools) developed beside the vegetated areas (FA 8), both along the active channel and within the floodplain (FA 6). The shallow margins of the pools, lakes and channels were commonly home to hydrophilous plants (palustrine conditions), the submerged parts of which became coated by calcite (facies Lst 1, FA 8 and the base of FA 3). The breakage of these plants (coated and uncoated) during floodings produced phytoclasts that accumulated (facies Lph) in nearby or far areas within marshy, dammed and free-flowing channel areas.

The moderately sloped stretch (Fig. 10A to C) occurred upstream, where the valley presented wide (up to 0.5 to $0.6 \mathrm{~km}$ across) and long areas separated by short narrow reaches. This stretch was characterized by the existence of large, standing or very slow-flowing water areas separated by barrages and barrage-cascade structures. Although the preserved deposits that can be interpreted to have corresponded to barrages and barrage-cascades in such stretch are limited to the El Molino site (AÑA M), it can be inferred that these structures also existed in other parts of the valley (for example, in Dévanos). This is suggested by the different altitudes of the flat areas (terraced) with standing-water deposits (for example, ca $20 \mathrm{~m}$ between ANA M and DEV in Fig. 10B) and their position with respect to narrow reaches along the valley (for example, southwest of Dévanos). These deposits most probably corresponded to barrage-cascade structures, which were primarily composed of moss phytoherms rather than phytoclastic tufas. These barrage-cascades were largely spaced, thereby allowing extensive dammed areas (i.e., shallow lakes, up to $c a 2 \mathrm{~km}$ long) to develop between them. The latter were characterized by the extensive deposition of bioclastic silts, sands and limestones that alternated with phytoclastic and marly sediments, in some cases rich in organic matter (peat), conforming to FA 7. Deposition in these areas would result from variable water 


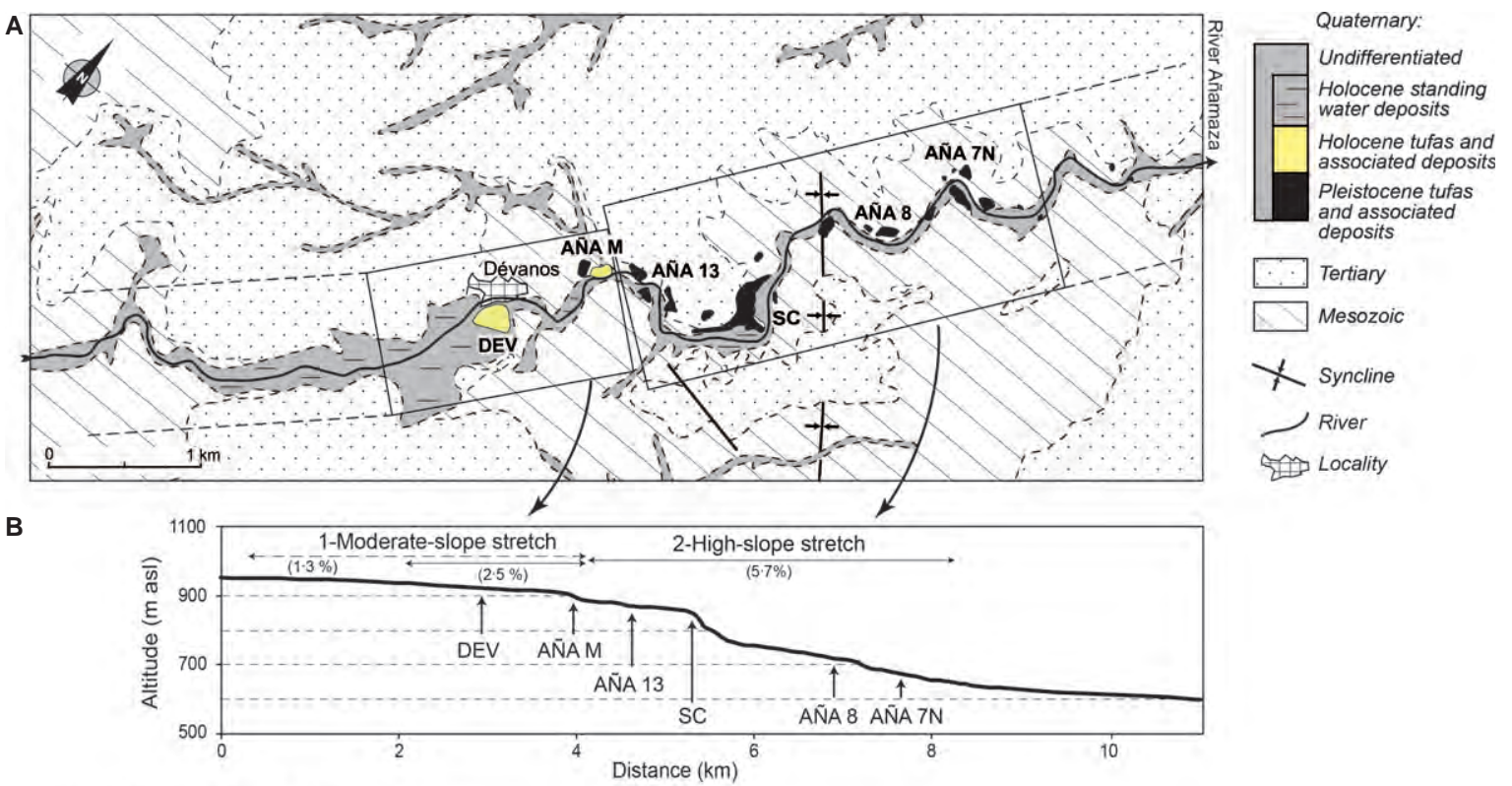

\section{1-Moderate-slope stretch}

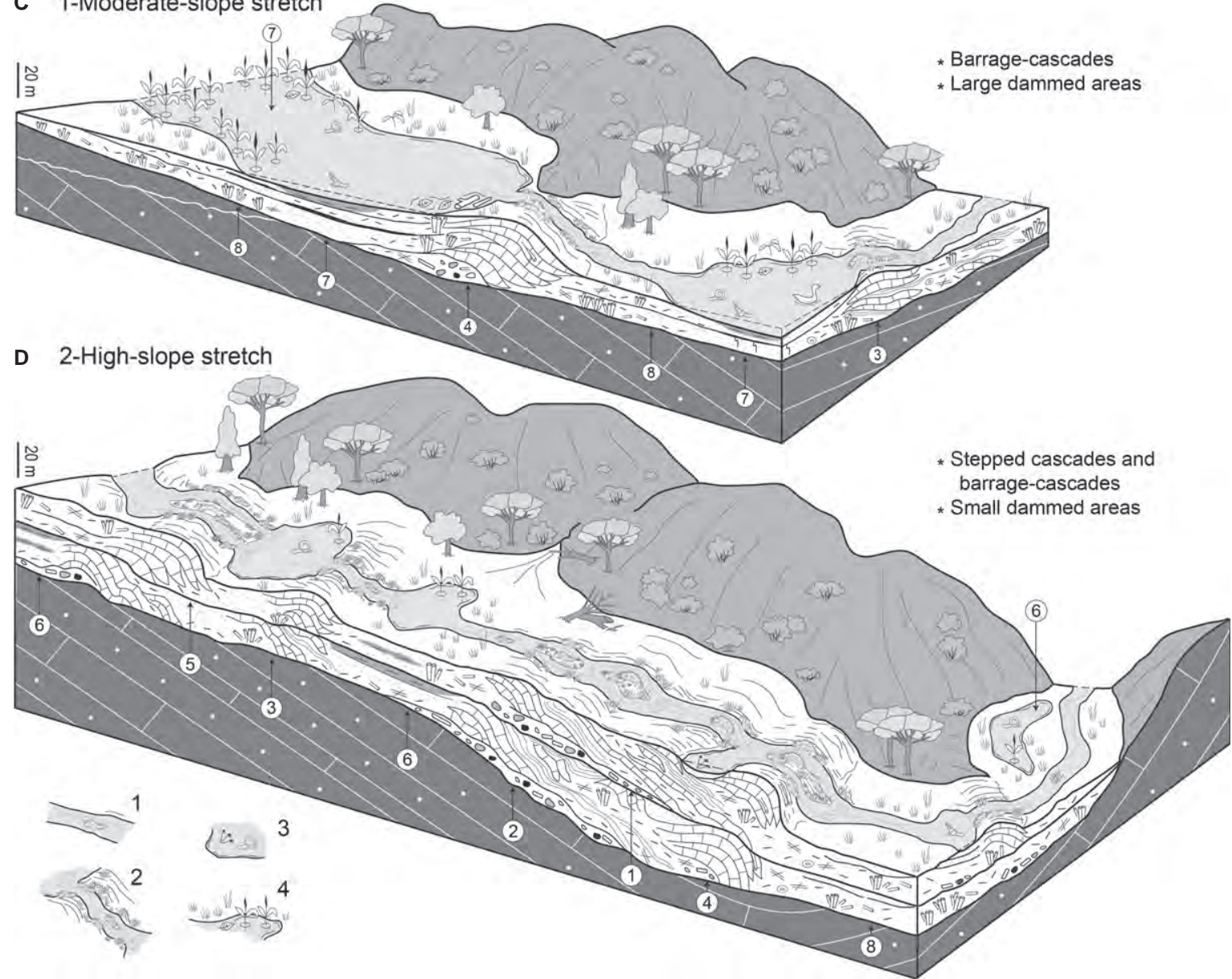

Fig. 10. Two sedimentary facies models proposed for the studied stepped fluvial system based on the existence of two main stretches with different slope along the valley. (A) Situation of the two main stretches within the studied area. (B) Longitudinal profile of the River Añamaza showing the location of the moderate-slope and highslope stretches. (C) Model for the moderate-slope stretch. (D) Model for the high-slope stretch. Legend: (1) river channel with small jumps; (2) barrage-cascades and cascades with bryophyte growth; (3) dammed areas and (4) palustrine areas. Legend for other symbols in Fig. 2. Encircled numbers in (C) and (D) refer to FAs of Fig. 9. 
inputs. In shallower and/or marginal areas, palustrine conditions would have developed, resulting in the formation of FA 8 . Smaller dammed areas (i.e., pools) could form between the closer barrage-cascade structures along the channel reaches with gentle to slightly moderate slopes (for example, FA 3). In general, the hydrophilous vegetation was common in the floodplain, the shallow margins of the standing water areas and the channel banks. Actually, another outstanding feature of the moderatesloped stretch was the abundance and preservation of phytoherm tufas of stems (bunches), which accounts for the palustrine conditions.

The highly sloped stretch (Fig. 10A, B and D) occurred downstream, where the general width of the valley was narrower (in general, less than $0 \cdot 3 \mathrm{~km}$ across). This stretch was characterized by the presence of close-up cascade and barragecascade structures (FAs 3, 4 and 5), which were primarily composed of moss phytoherms and phytoclastic tufas. Small dammed areas could develop between these structures. In the less steep reaches, pools would also form along the channel and in the floodplain (for example, FA 6). However, the most significant feature of this stretch was the existence of an extensive steep reach of the river with a highly irregular surface (for instance, small steps), in which erosional processes were common. Coarse polygenic extraclasts and phytoclasts deposited as lenticular and wedge-shaped bodies over steep channel surfaces (FA 1) in relation to erosional processes. Stromatolitic and moss phytoherms would constitute stepped cascades (i.e., non-vertical, inclined, hemi-domed or convex-shaped surfaces) (FA 2), in which changing flow conditions caused the alternation of these two facies. Some of these cascades could evolve into moss-dominated barragecascade structures, mostly with vertical falls, thereby allowing the development of small dammed areas upstream (for example, conforming to FA 4). Nevertheless, the dammed areas were limited to the moments of great growth of the barrages. The steep slope of that part of the valley also limited the development of wide vegetated areas (i.e., with rooted hydrophilous plants), and it would indeed favour the erosional processes (as recognized by the presence of deep incisions and coarse sediments, such as facies $G$ and Lph, in the Salto del Cajo area; Fig. 2B). In general, the deposition of the highly sloped stretch was characterized by the abundance of cascade and barrage-cascade structures and the rarity of preserved phytoherms of stems (Lst 1).
Overall, the sedimentological and hydrological differences between the Pleistocene and Holocene fluvial systems can be referred to the highslope model and the moderate-slope model, respectively, within a general stepped context. However, these two models should be considered as representative of different depositional contexts that may coexist within a single sedimentation area.

\section{STABLE ISOTOPE COMPOSITION OF THE CARBONATE FACIES}

The stable isotope composition of the carbonate facies $(n=55$; all of them composed of $>98 \%$ calcite) ranges between $-9.4 \%$ and $-5 \cdot 3 \%$ V-PDB (mean $=-7.5 \pm 0.63)$ for $\delta^{18} \mathrm{O}$, and between $-7.4 \%$ and $-2.9 \%$ V-PDB (mean $=-6.0 \pm 0.72$ ) for $\delta^{13} \mathrm{C}$ (Table 2; Fig. 11). These values are within the range of other fluvial tufa deposits (Andrews et al., 1997, 2000; Arenas et al., 2000; Smith et al., 2004; Ordóñez et al., 2005; Andrews, 2006).

As a whole, the Holocene samples have slightly higher values of $\delta^{18} \mathrm{O}(n=11$; mean $\delta^{18} \mathrm{O}=-7 \cdot 1 \pm 0 \cdot 37 \%$ ) than the Pleistocene samples $\left(n=44\right.$; mean $\delta^{18} \mathrm{O}=-7 \cdot 6 \pm 0 \cdot 66 \%$ ). In contrast, the mean $\delta^{13} \mathrm{C}$ values are similar in both cases (mean Holocene $=-5 \cdot 9 \pm 0 \cdot 48 \%$ and mean Pleistocene $=-6 \cdot 1 \pm 0 \cdot 78 \%$ o , although with a considerably wider range of variation in the Pleistocene. Although there is a great overlap among the different samples, some isotopic differences can be observed (Fig. 11). Some of these differences refer to slight increases in the $\delta^{18} \mathrm{O}$ and $\delta^{13} \mathrm{C}$ mean values of some facies in the Holocene compared to the same facies in the Pleistocene (for example, facies Lph, Lst, Lbr and Ls; facies Lb, Li, M and Lsp are only present in the Pleistocene deposits), with mean value differences from 0.3 to $0.5 \%$ for both isotopes. Such differences are more pronounced for facies Sb. As an exception, the mean $\delta^{13} \mathrm{C}$ value of facies Ls is $\mathrm{ca} 0.6 \%$ lower in the Holocene than in the Pleistocene. These results might suggest a higher, but rather variable, precipitation/evaporation ratio in the Pleistocene, and drier conditions in the Holocene, which is in agreement with the overall drier climate conditions reported for the Holocene in the Mediterranean region (e.g. Cacho et al., 2010; Candy et al., 2012).

The correlation between the $\delta^{18} \mathrm{O}$ and $\delta^{13} \mathrm{C}$ values is $r=0.70$ for the Pleistocene samples and $r=0.72$ for the Holocene samples. In addition, the mean $\delta^{18} \mathrm{O}$ and $\delta^{13} \mathrm{C}$ values and 
Table 2. Stable-isotope composition of carbonate facies analysed in the Añamaza River valley. Samples consist of calcite $(>98 \%)$ and minor amounts of quartz, phyllosilicates and iron-sulphur minerals. Sample labels refer to the stratigraphical sections shown in Figs 2, 5 and 6.

\begin{tabular}{|c|c|c|c|}
\hline Sample & Facies & $\begin{array}{l}\delta^{13} \mathrm{C} \\
(\% \text { V-PDB })\end{array}$ & $\begin{array}{l}\delta^{18} \mathrm{O} \\
(\% \mathrm{~V}-\mathrm{PDB})\end{array}$ \\
\hline AÑNA M-15 & Ls & $-6 \cdot 36$ & $-6 \cdot 83$ \\
\hline AÑA M-14 & $\mathrm{Sb}$ & $-6 \cdot 40$ & $-7 \cdot 46$ \\
\hline AÑA M-13 & Lphf & $-6 \cdot 33$ & $-7 \cdot 38$ \\
\hline ANA M-12 & Lst 1 & $-5 \cdot 60$ & $-6 \cdot 94$ \\
\hline AÑNA M-12s & Ls & $-6 \cdot 71$ & $-7 \cdot 99$ \\
\hline AÑA M-7 & Lbr & $-5 \cdot 72$ & $-7 \cdot 05$ \\
\hline AÑ A M-5 & $\mathrm{Sb}$ & $-5 \cdot 65$ & $-7 \cdot 05$ \\
\hline AÑ A M-4 & Lph & $-5 \cdot 29$ & $-6 \cdot 65$ \\
\hline AÑ A M-2 & $\mathrm{Sb}$ & $-5 \cdot 35$ & $-6 \cdot 95$ \\
\hline AÑ $A$ M-1a & Lbr & $-5 \cdot 59$ & $-7 \cdot 15$ \\
\hline AÑA M-H-1 & $\mathrm{Sb}$ & $-6 \cdot 03$ & $-6 \cdot 86$ \\
\hline AÑ & Lph & $-6 \cdot 72$ & $-7 \cdot 39$ \\
\hline AÑA $7 \mathrm{~N}-15$ & Lst 1 & $-6 \cdot 68$ & $-7 \cdot 61$ \\
\hline AÑA 7N-14 & $\mathrm{Lph}$ & $-6 \cdot 32$ & $-6 \cdot 92$ \\
\hline AÑ & Lbg & $-6 \cdot 53$ & $-7 \cdot 29$ \\
\hline AÑA $7 \mathrm{~N}-12$ & $\mathrm{Lph}$ & $-6 \cdot 72$ & $-7 \cdot 89$ \\
\hline AÑ & $\mathrm{Lbr}$ & $-6 \cdot 41$ & $-7 \cdot 55$ \\
\hline AÑA $7 N-9$ & Lbr & $-6 \cdot 58$ & $-7 \cdot 72$ \\
\hline AÑA $7 \mathrm{~N}-7$ & $\mathrm{M}$ & $-7 \cdot 40$ & $-6 \cdot 96$ \\
\hline ANA $7 \mathrm{~N}-4$ & Lph & $-6 \cdot 47$ & $-7 \cdot 92$ \\
\hline AÑA $7 \mathrm{~N}-1$ & Lph & $-6 \cdot 64$ & $-8 \cdot 08$ \\
\hline C-1-26 & $\mathrm{Lbr}$ & $-5 \cdot 58$ & $-7 \cdot 18$ \\
\hline C-1-25 & Lst 2 & $-5 \cdot 65$ & $-7 \cdot 37$ \\
\hline C-1-24 & Ls & $-5 \cdot 65$ & $-7 \cdot 30$ \\
\hline C-1-22.2 & Lsp & $-6 \cdot 62$ & $-7 \cdot 89$ \\
\hline C-1-22.1 & $\mathrm{Ls}$ & $-6 \cdot 52$ & $-7 \cdot 76$ \\
\hline C-1-21 & Lbr & $-5 \cdot 92$ & $-7 \cdot 09$ \\
\hline C-1-20 & Ls & $-6 \cdot 15$ & $-8 \cdot 29$ \\
\hline C-1-19 & Lbr & $-6 \cdot 71$ & $-7 \cdot 97$ \\
\hline C-1-18 & Lst 1 & $-6 \cdot 36$ & $-7 \cdot 49$ \\
\hline C-1-16 & Ls & $-6 \cdot 61$ & $-8 \cdot 61$ \\
\hline C-1-15 & Lph & $-6 \cdot 29$ & $-7 \cdot 35$ \\
\hline C-1-12 & Ls & $-6 \cdot 54$ & $-8 \cdot 16$ \\
\hline C-1-11 & Lbr & $-6 \cdot 24$ & $-8 \cdot 42$ \\
\hline C-1-10 & Ls & $-5 \cdot 18$ & $-7 \cdot 03$ \\
\hline C-1-9 & Ls & $-5 \cdot 58$ & $-7 \cdot 51$ \\
\hline C-1-4 & Ls & $-5 \cdot 27$ & $-7 \cdot 82$ \\
\hline C-1-3 & $\mathrm{Lb}$ & $-5 \cdot 08$ & $-7 \cdot 36$ \\
\hline C-1-1 & Lbr & $-5 \cdot 18$ & $-7 \cdot 66$ \\
\hline C-2-16 & $\mathrm{Sb}$ & $-6 \cdot 97$ & -8.58 \\
\hline C-2-15 b & $\mathrm{Lb}$ & $-7 \cdot 07$ & $-8 \cdot 23$ \\
\hline C-2-15 a & $\mathrm{Lb}$ & $-6 \cdot 90$ & $-8 \cdot 11$ \\
\hline C-2-13 & $\mathrm{Sb}$ & $-6 \cdot 92$ & $-9 \cdot 36$ \\
\hline C-2-9 & Lbr & $-6 \cdot 15$ & $-7 \cdot 73$ \\
\hline C-2-7 & Lbr & $-6 \cdot 42$ & $-7 \cdot 52$ \\
\hline C-2-3 & $\mathrm{Lph}$ & $-5 \cdot 58$ & $-6 \cdot 89$ \\
\hline C-2-2 & $\mathrm{Lb}$ & $-5 \cdot 61$ & $-7 \cdot 40$ \\
\hline C-3-8 & Lph+Ls1 & $-5 \cdot 86$ & -6.94 \\
\hline C-3-6 & Ls & $-6 \cdot 08$ & $-7 \cdot 57$ \\
\hline C-3-4 & Lph & $-6 \cdot 06$ & $-7 \cdot 40$ \\
\hline C-3-2 b & $\mathrm{Li}+\mathrm{Lb}$ & $-2 \cdot 91$ & $-5 \cdot 27$ \\
\hline
\end{tabular}

Table 2. (continued)

\begin{tabular}{llll}
\hline Sample & Facies & $\begin{array}{l}\delta^{13} \mathrm{C} \\
(\% \text { V-PDB })\end{array}$ & $\begin{array}{l}\delta^{18} \mathrm{O} \\
(\% \text { V-PDB })\end{array}$ \\
\hline C-3-2 a & Li+Lb & $-4 \cdot 63$ & $-6 \cdot 28$ \\
C-4-6 & Lst 2 & $-5 \cdot 49$ & $-7 \cdot 20$ \\
C-4-1 b & Lb & $-6 \cdot 08$ & $-7 \cdot 46$ \\
C-4-1 a & Lph & $-6 \cdot 01$ & $-7 \cdot 24$ \\
\hline
\end{tabular}

correlation coefficient of all samples of moss phytoherms (Lbr; $r=0.50, n=11$ ) are almost equal to those of stromatolites (Ls; $r=0.51$, $n=10$ ), thus suggesting similar conditions for the formation of facies Lbr and Ls in rapids, cascades and jumps related to free-flowing water. On the contrary, there is a large range of variation in the $\delta^{18} \mathrm{O}$ and $\delta^{13} \mathrm{C}$ values for the entire group of facies $\mathrm{Sb}, \mathrm{Lb}$ and $\mathrm{Li}$ (all samples included) with a good correlation $(r=0 \cdot 88$, $n=14$ ). All of these facies formed in slow-flowing and standing water areas (Table 1). Furthermore, both the Holocene and the Pleistocene samples present similar isotopic differences among facies, with slightly higher $\delta^{18} \mathrm{O}$ values of the stem phytoherms and phytoclastic facies (Lst and Lph; $n=17$ ) and of the bioclastic facies ( $\mathrm{Lb}$ and $\mathrm{Li} ; n=8$ ) with respect to stromatolites (for the Pleistocene samples, mean $\delta^{18} \mathrm{O}$ of Lst and Lph is $0.4 \%$ higher than Ls; mean of Lb and $\mathrm{Li}$ is $0.8 \%$ o higher than Ls). These results are in agreement with the longer residence time of water in slow-flowing and standing water areas (facies $\mathrm{Sb}, \mathrm{Lb}$ and $\mathrm{Li}$ ) and in areas with dense hydrophilous vegetation (facies Lst 1 and Lph) compared with the sites where stromatolites and moss phytoherms formed (channel reaches of moderate to steep slope), with permanent renewal and fast flow of water. The correlation between $\delta^{18} \mathrm{O}$ and $\delta^{13} \mathrm{C}$ values is consistent with the existence of standing water areas during the Pleistocene and Holocene because both isotopes may covary in standing water bodies subject to evaporation (Talbot \& Kelts, 1990; Leng \& Marshall, 2004). However, other kinetic effects cannot be disregarded.

With respect to the general isotopic variations through time, although the Pleistocene samples correspond to different depositional units (i.e., MISs 9, 7 and 5), the isotopic composition does not group the samples by age. To test whether this type of grouping exists, a larger number of analysed samples of the different units would be necessary. The only remarkable fact is the large variation in the $\delta^{18} \mathrm{O}$ and $\delta^{13} \mathrm{C}$ values of facies $\mathrm{Lb}$ and $\mathrm{Li}$ in 


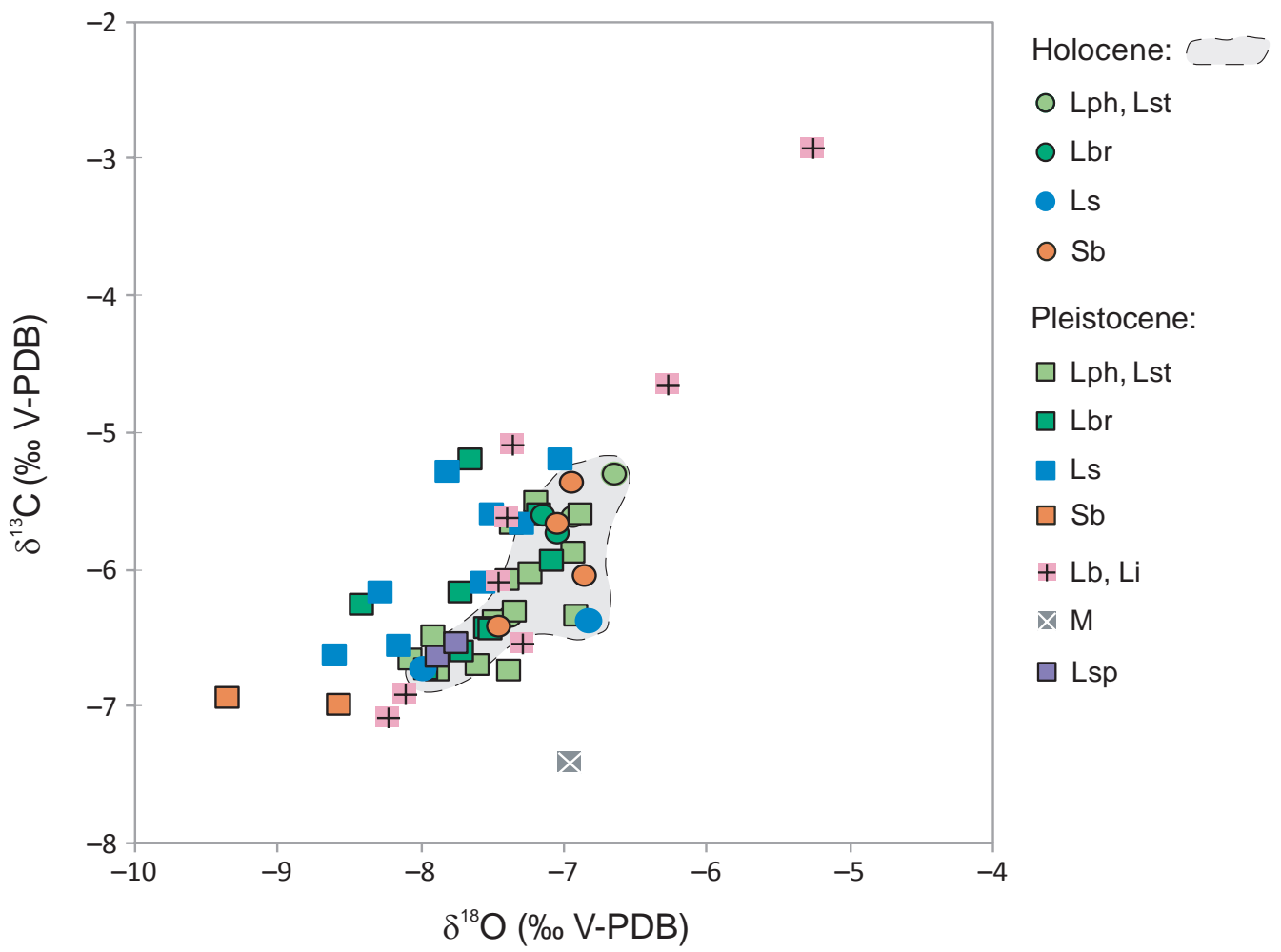

Fig. 11. Plot of $\delta^{13} \mathrm{C}$ versus $\delta^{18} \mathrm{O}$ values of the carbonate facies in the Añamaza River valley.

the Pleistocene, which probably indicates changing residence time of the water in the pools and the variable influence of organic matter $\left({ }^{12} \mathrm{C}\right.$-rich sediment), probably caused by variations in the precipitation/evaporation ratio during this epoch.

\section{DISCUSSION}

Many present-day tufas are formed in stepped river valleys, as did many fluvial Quaternary tufas. The two depositional models defined for the Quaternary Añamaza valley represent stepped situations with variable slopes, as defined by Arenas-Abad et al. (2010), to refer to a context opposite to the low-gradient, non-stepped conditions. Within this stepped context, some examples that fit the moderate-slope model are the present-day and Holocene tufa system of Alcaraz (García del Cura et al., 1997) and the Ruidera pools (Ordóñez et al., 2005), and the Pleistocene tufa system of the Mesa River (Vázquez-Urbez et al., 2012); all of these systems are in Spain. Similarly, some reaches of the present tufa-depositing Krka, Korana and Zrmaja Rivers in Croacia (e.g. Horvatinčić et al., 2003) and the Holocene Caerwys and Alport sites in the southern United Kingdom (Pedley et al., 1996, 2000), have moderate slopes, generally lower than $1.3 \%$, reaching up to $c a$ $1.7 \%$ in some reaches. In most of these cases, large dammed water bodies exist in the flat areas between successive topographical breaks (Arenas-Abad et al., 2010). In the case of Alcaraz, these standing water areas are very shallow with extensive palustrine zones (for instance, with a similar facies succession to that in FA 8 of this work). With regard to the high-slope model, the Pleistocene deposits of the middle-low course of the Piedra River (north-east Spain) fit such a situation (Vázquez-Urbez et al., 2012) because the general slope is $c a 2$ to $3 \%$ with short stretches up to $11 \%$. Smaller dammed areas commonly occurred in those cases. Nevertheless, none of those examples has such a high gradient as the highly sloped stretch in the Pleistocene record of the Añamaza valley (Fig. 10D), which represents very high gradient conditions. In fact, the grossgeometry of deposits in some segments within this highly sloped stretch (i.e., the Salto del Cajo area) compare well with the "perched springline tufa model' of Pedley et al. (2003) and the 'slope system' of Violante et al. (1994). Nevertheless, in the study area, some types of facies and facies associations are different and, indeed, these deposits formed along a river course within a steep ramp-like longitudinal profile. This result 
is one of the most noticeable findings of the study of this area; actually, the analysis of the Pleistocene and Holocene record allows some new general conclusions to be drawn about the sedimentary fill of tufa valleys and the evolving growth style of the tufa in knickpoints, which is discussed below.

\section{Controls on the geometry of the valley fill}

The Quatenary Añamaza tufas and associated facies primarily formed in a stepped fluvial valley with a single channel. The different slopes of the two stepped stretches (Fig. 10C and D) were controlled mainly by the different bedrock lithologies along the valley (Figs $1 \mathrm{~B}$ and 10). The moderately sloped stretch includes large flat areas formed in relation to less resistant bedrock, which is mostly composed of horizontal, Tertiary detrital and carbonate deposits. In contrast, the narrower reaches along the moderately sloped stretch and the majority of the highly sloped stretch occur in relation to a folded and fractured, more resistant bedrock (Mesozoic limestones and strongly lithified fine detrital, mostly siliciclastic, deposits) and are commonly steeper.

In this stepped system, water was held back in flat areas that existed between barrage-cascades that formed at narrow passes and/or at reaches of increased slope. The formation of the cascades and barrage-cascades was therefore related to bedrock topographical discontinuities along the longitudinal profile of the river that mostly occurred in places with different bedrock lithological units in contact, in part favoured by the tectonic structure. The path of the present river through the Mesozoic rocks shows almost perpendicular segments, which provides evidence of its structural control (see Fig. 1B). These steeply sloped areas along the river (i.e., knickpoints) favoured rapid $\mathrm{CO}_{2}$-degassing from water, therefore causing thick accumulation of tufa on such steep reaches (for example, cascades and barragecascades) which would exaggerate the initial bedrock topography in those zones (e.g. Weijermars et al., 1986; D’Argenio \& Ferreri, 1988; Pedley, 1990, 2009; Ford \& Pedley, 1996; Carthew et al., 2003, 2006; Viles et al., 2007; Capezzuoli et al., 2009). In addition, these knickpoints conditioned the distribution and extent of distinct depositional environments along the valley (Pedley et al., 2000). At present, the highest deposition rates (up to $1.8 \mathrm{~cm} \mathrm{yr}^{-1}$; Pentecost, 1978; Drysdale \& Gillieson, 1997; Gradziński, 2010; Vázquez-Urbez et al., 2010, 2011 in fluvial tufa systems occur in rapids, jumps, cascades and barrage-cascades, that is, in fast-flowing water and high turbulence conditions; in contrast, slowflowing and standing water areas are loci of smaller deposition rates (e.g. Drysdale \& Gillieson, 1997; Vázquez-Urbez et al., 2010, 2011; Arenas et al., 2014).

The distribution and extent of diagnostic tufa facies along the fluvial valleys can therefore be good indicators of differences in the slope along a fluvial valley (Vázquez-Urbez et al., 2012). The development of cascade and barrage-cascade facies associations, along with the limited development of dammed areas, through short space intervals can be associated with higher gradient stretches. In contrast, when these structures appear largely separated by extensive dammed deposits, lower gradient stretches probably occurred (cf. fig. 10 in Vázquez-Urbez et al., 2012). These two situations correspond to the highly sloped and moderately sloped stretches recognized in the Añamaza valley (Fig. 10), which primarily coincide with the preserved Pleistocene and Holocene records, respectively.

Therefore, the geometry and thickness of the sedimentary fill of the fluvial valley (for example, depositional units between consecutive knickpoints) are distinct for each of the two situations; initially, the geometry and thickness were dependent on the bedrock lithology and structure and were then conditioned by ongoing tufa deposition (primarily the aggradation/progradation ratio at the knickpoints; e.g. Violante et al., 1994; Pedley et al., 2000). Thus, the initial process in a stepped fluvial system would be to create wedge-shaped depositional units (primarily composed of deposits of cascades and barrage-cascades downstream, and of standing water and gentle-slope channel areas upstream) that open downstream due to the thicker accumulation of tufa at the knickpoints (i.e., larger tufa depositional rates at the steep channel reaches, cascades and barrage-cascades). Accordingly, larger wedges with a large length/ height $(\mathrm{L} / \mathrm{H})$ ratio would form in stretches with a lower slope, in which a significant amount of the deposits would correspond to the dammed facies and the other low-slope facies. In contrast, small wedges with a low $\mathrm{L} / \mathrm{H}$ ratio would develop in stretches of higher slope, generally with less extensive deposits of dammed facies (Fig. 12A).

These depositional wedges would be more liable to erosion when developed on steep stretches (Fig. 12A and B). In such situations, during erosional periods, the depositional wedges would be partially destroyed, giving rise to a new, more 
A

GEOMETRY OF THE VALLEY FILL

1-Large wedges (moderate-slope stretches)

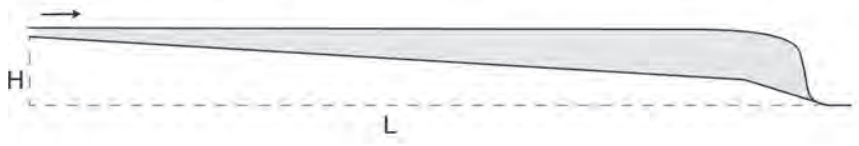

2-Small wedges (high-slope stretches)

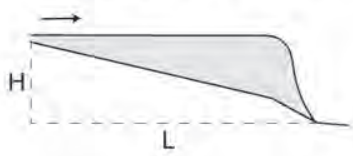

$\rightarrow$ Low water discharge
B DEVELOPMENT OFA MULTI-STOREY

DEPOSITIONAL WEDGE

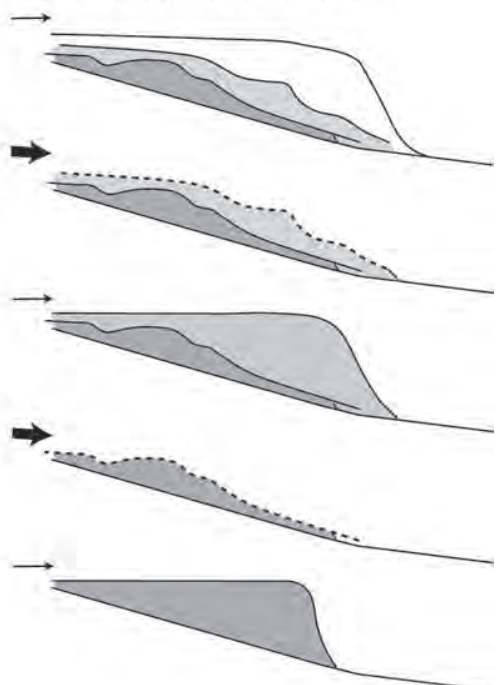

Fig. 12. Depositional architecture for a stepped fluvial tufa system. (A) Geometry of the valley fill. (B) Development of a multi-storey depositional wedge.

uniform (regularized) steep slope in such parts of the valley. This process would produce a new topographical profile where basal deposits consisting of coarse detrital sediments would be followed by tufa deposition to construct a new wedged build-up or unit. This situation would produce stacked lenticular and wedge-shaped deposits or multi-storey wedges (Fig. 12B). The Salto del Cajo build-up would correspond to the thicker part (mostly the knickpoint) of one of those multi-storey wedges that show a complex aggradation-progradation process interrupted by erosional events (Fig. 2B). The 'prograding phytohermal wedges' described by Guerrero-Domínguez \& GonzálezMartín (2000) in the upper stretch of the River Tagus (Spain) also compare well with a multistorey wedge formed in high-slope conditions. The evolution of the depositional wedges produced in moderately sloped stretches is more difficult to envisage, because the outcropping record in the study area does not show superposed units (i.e., just one single depositional unit can be observed at each site).

\section{Controls on the geometry of the cascades and cascade-barrage structures}

Within the above-mentioned wedge-shaped depositional units, the extent and type of facies may also vary depending upon the geometry of the knickpoint reaches (Fig. 13), which would control the growth style or the type of tufa struc- ture that would form at the downstream part of the wedges; in other words, the types of cascades or barrage-cascades. Cascades and barrages have been classified according to their shape (e.g. Golubić, 1969; Pentecost \& Viles, 1994; Carthew et al., 2003). The causes of the varied morphologies and deposition rate of the cascades and barrage-cascades have been associated with changes in the discharge, water velocity and climate conditions (Pedley, 1990; Pedley et al., 1996; Viles \& Pentecost, 1999).

The steep reaches along a river can present different geometrical configurations for a given difference in height between two points. Commonly, such configurations represent the bedrock topography, but they may also correspond to surfaces produced by the later growth of tufa and erosional phases. Figure 13 shows several possible shapes for knickpoint reaches. For instance, a ramp with small irregularities, a single, non-vertical step or a single vertical step (Fig. 13A to C). There are, of course, other intermediate geometric configurations (for example, multiple steps). In all of these cases, the aggradation/progradation ratio (A/P) of the tufa deposits on such surfaces would determine the growth style of the cascade or barrage-cascade, and the extent of the upstream dammed areas. In all cases, large dammed areas would only form in relation to knickpoints with aggradation, which would therefore constitute barrages. Decreasing aggradation at the knickpoints would 
A- Ramp

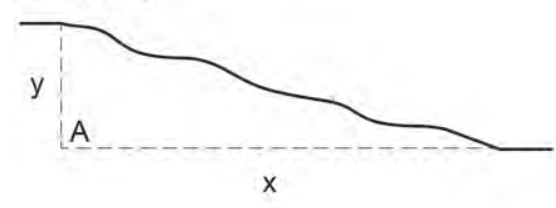

B- Single, non-vertical step
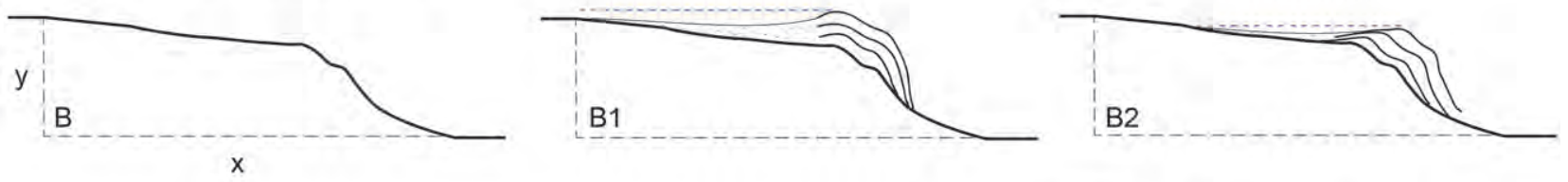

C- Single, vertical step
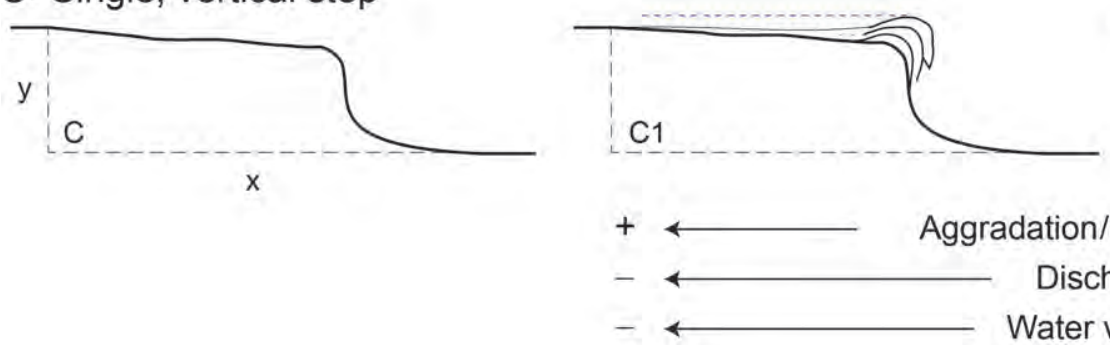

Aggradation/Progradation

Discharge

Water velocity

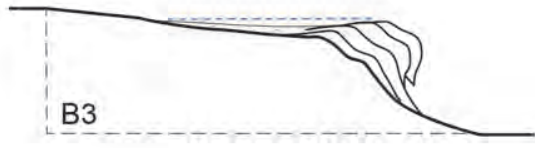

Fig. 13. Proposed patterns of growth style of cascades as a function of the knickpoint geometry and the aggradation/progradation ratio.

yield smaller dammed areas, perhaps with thinner deposits, and increasing progradation would produce more extensive cascade and barragecascade bodies in the flow direction.

Focusing the discussion on the examples shown in Fig. 13, on an irregular ramp-like surface (Fig. 13A), several mounds or asymmetrical domes would form, giving rise to a highly irregular surface composed of several jumps or small cascades (for example, consisting of facies Lph, Lbr and Ls). Some of these cascades could correspond to stepped cascades, similar to that encircled in Fig. 13A2 (for instance, with deposits arranged as FA 2; Fig. 9). In some cases, prograding wedges (for example, as represented by FA 1) might form in some parts of the ramp, most probably during higher discharge periods. Very small or absent dammed areas would exist in this ramp-like situation. Increasing the flow velocity or discharge rate would reduce the aggradation at the top of the cascades and favour the formation of stromatolite-made prograding stepped cascades. In the case of a knickpoint with a single, non-vertical step (Fig. 13B), tufas would grow and conform to a hemi-domed barrage-cascade (for example, convex-shaped cascade) with well-developed upstream dammed areas. In most cases, low-flow areas within the cascades are loci for the thick growth of moss mounds. Increasing the discharge might result in a decrease in the $\mathrm{A} / \mathrm{P}$ ratio, thereby leading to a primarily prograding structure (Fig. 13B2) and even to the creation of overhangs (Fig. 13B3). Facies associations 4 and 5 (Fig. 9) fit these configurations. Finally, in a vertical step, most tufa growth would concentrate on the upper front of the cascade (for example, with facies Lph and Lbr), which would produce a dam that would 
hold water back (Fig. 13C1). With increasing discharge, the $\mathrm{A} / \mathrm{P}$ ratio of the barrage-cascade would diminish, and then become a vertical cascade (waterfall) with overhangs and caves underneath. This configuration is partially recorded by FA 4 (Fig. 9).

High discharge would reduce the growth in the aggrading part and the cascades would most probably develop only in the horizontal direction (prograding, toplap geometry). In contrast, very low discharge could produce a general decrease in the growth or even a degrading process.

In this study, some parts of the Pleistocene Salto del Cajo build-up exhibit a vertical passage from deposits formed on a ramp-like situation (i.e., steep channel, stepped cascade FAs) to the deposits formed on single, vertical steps (i.e., representing vertical barrage-cascades) and upstream associated dammed facies. This evolution implies a prevailing aggradation process at the front of the knickpoint and is in agreement with the natural tendency of tufa to form wedges that thicken downstream.

To summarize, the initial geometry of the knickpoints and the variations of the tufa aggradation/progradation ratio (for example, related to changes in the discharge/water velocity) control the growth style of the cascades and barrages in different parts along a river valley. Therefore, these parameters control the extent, thickness and vertical evolution of deposits formed in the upstream dammed and gentlesloped river stretches within the wedged units.

\section{Palaeoclimatic significance of the tufa and associated facies record}

From the available chronological data for the Añamaza tufa deposits (Arenas et al., 2010; Vázquez-Urbez et al., 2011), two main periods of tufa deposition $(\approx 128$ to $80 \mathrm{ka}$ and $\approx 10.6$ to $0.15 \mathrm{ka}$ ) that correlate to MIS 5 (mostly 5e but also $c a$ 5c and 5a) and MIS 1 are distinguished. In addition, tufa sedimentation is also recorded during MIS $7(\approx 204 \mathrm{ka}: 7 \mathrm{a})$ and MIS $9(\approx 282 \mathrm{ka}$ : 9a). Therefore, a close relation can be established between the main periods of tufa formation and the warm conditions that characterize such odd-numbered isotopic stages, as inferred from the $\delta^{18} \mathrm{O}$ curve published by Gibbard et al. (2005) (Fig. 14A). Furthermore, within that curve, the intervals $7 \mathrm{a}$ and 9a also coincide with relative increases in temperature.

This result is in agreement with the increased tufa growth recorded during odd-numbered MISs that is widely recognized in temperate climate zones (Hennig et al., 1983) and also in the Iberian Peninsula (Martínez-Tudela et al., 1986; MartínAlgarra et al., 2003; Ordóñez et al., 2005; Ortiz et al., 2009; Domínguez-Villar et al., 2011). Pedley (2009) indicated that tufa deposition reached a maximum during warm and wet interglacial periods in the Mediterranean region. Hennig et al. (1983) placed the tufa maximum in this area at 100 to $110 \mathrm{ka}$. Similarly, the major tufa growth episodes appear to coincide with peaks of Northern Hemisphere insolation (Fig. 14B), which supports the correlation of tufa accumulation to warm conditions (Frank et al., 2000).

However, some cold periods, which are correlatable to the even-numbered marine isotopic stages, do not appear to have been unfavourable for the formation of tufa deposits. In fact, in the Iberian Range and other areas of the Iberian Peninsula, tufas have been reported during MISs 8 and 6 (Martínez-Tudela et al., 1986; Durán, 1989; Peña et al., 2000; Valero-Garcés et al., 2008; Sancho et al., 2010; Lozano et al., 2012) which are characterized by overall cold climate conditions on the global scale. Nonetheless, these tufas primarily occurred during the warmer and/or wetter intervals of such stages; indeed, these warm conditions could be reinforced in low latitude areas, such as the Iberian Peninsula, where the climate during even-numbered MISs would not be so unfavourable (Martín-Algarra et al., 2003).

There is no tufa record during MISs 4, 3 and 2 in the Añamaza valley, which is in agreement with the prevailing adverse conditions that rather favoured the occurrence of large glacial and fluvial non-carbonate archives in the northeastern Iberian Peninsula (Lewis et al., 2009; Benito et al., 2010). A marked decrease in temperature is inferred for that time span from the isotope curve in Fig. 14. Thus, for the Middle and Late Pleistocene, an evolutionary pattern composed of alternating periods of warm, favourable conditions with tufa accumulation in the Añamaza River valley and cold, adverse conditions with glacial advances, periglacial activity and terrace formation (Fuller et al., 1998; Lewis et al., 2009; Benito et al., 2010; García-Ruiz et al., 2013) in the northern sector of the Iberian Peninsula can be deduced (Fig. 14).

In the Añamaza valley, the periods with tufa formation were characterized by overall warm and wet climate conditions that favoured the development of forest vegetation, soil-derived $\mathrm{CO}_{2}$ production, karstic activity and groundwater discharges rich in bicarbonate and calcium ions. 


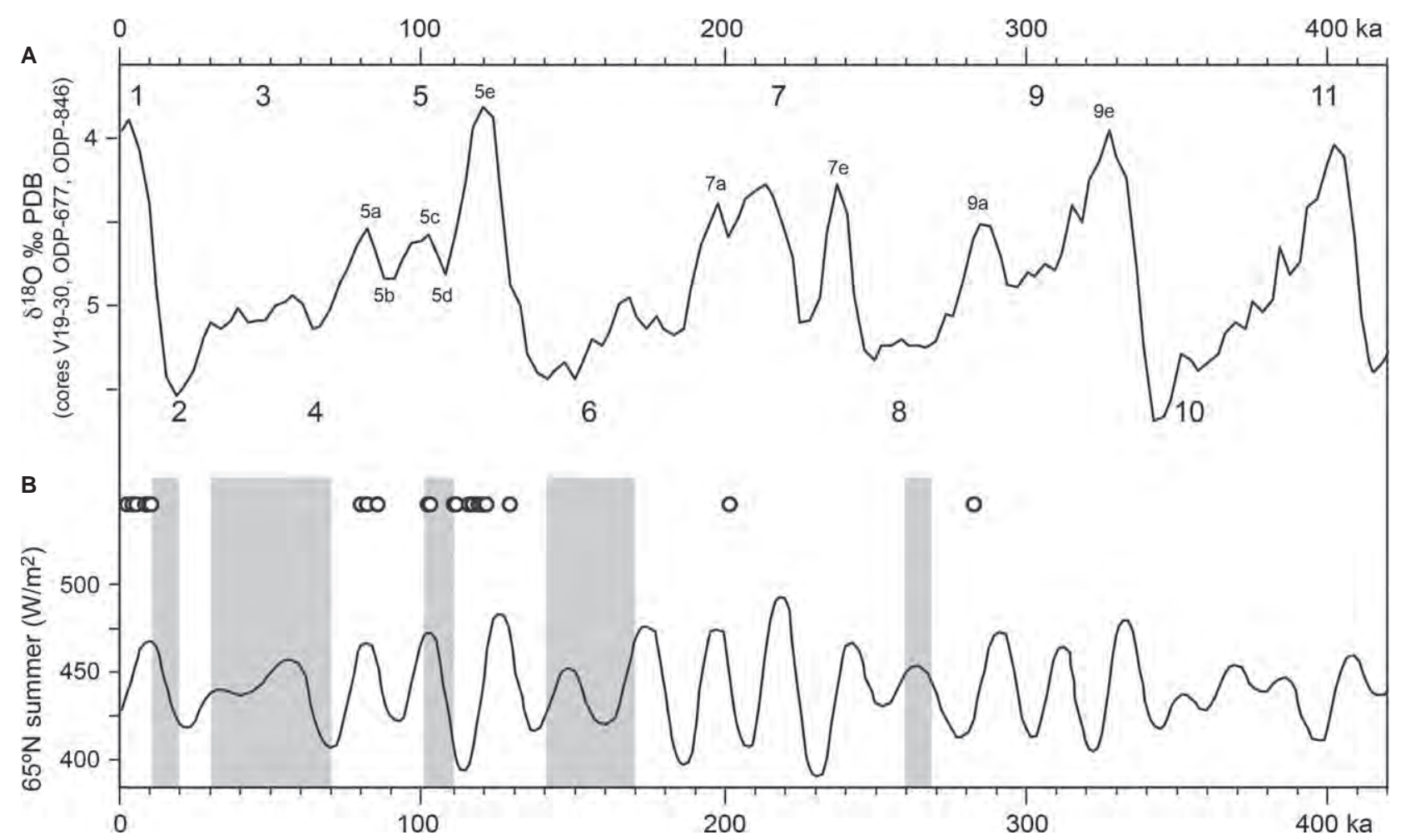

Fig. 14. Temporal distribution of tufa deposits in the Añamaza River valley (circles, adapted from Arenas et al., 2010) in relation to other global and regional palaeoenvironmental records: (A) $\delta^{18} \mathrm{O}$ curve and marine isotope stages from Gibbard et al. (2005). (B) Insolation at $65^{\circ} \mathrm{N}$ during summer (based on Berger \& Loutre, 1991). Vertical grey bars show cold phases in the NE Iberian Peninsula (based on Lewis et al., 2009; Benito et al., 2010; GarcíaRuiz et al., 2013).

This general context involves the biologically controlled landscape stability (Goudie et al., 1993). These conditions were reinforced during MIS 5, leading to the formation of the most important tufa build-ups in the study area. During this time span, several erosional stages with partial destruction of tufa deposits have been identified in the Añamaza valley. These stages are related to short periods of climate change, most likely with an increase in extreme hydrological events within a semiarid context in which forest habitats would have been partially destroyed. This result agrees with the frequency of coarse detrital deposits (including trunks, branches, pine-cones and large bedrock fragments) associated with erosional surfaces in the MIS 5 deposits. The rarity of the preserved phytoherms of stems during the Pleistocene record, in contrast with their abundance in the Holocene record, is also evidence of higher energy processes and/or more frequent erosional events in the former.

The environmental conditions of the MIS 1 were favourable for tufa formation in the Añamaza valley, but it appears that the optimum conditions assessed for the MIS 5 were attenuated, most likely due to a decrease in water availability. This fact has been recorded by the slight increase in $\delta^{18} \mathrm{O}$ and $\delta^{13} \mathrm{C}$ values of the studied samples (Fig. 11) and indeed agrees with climate studies in other areas of the western Mediterranean (Moreno et al., 2012). This stage includes the Holocene Climate Optimum ( $c a 11.7$ to $5 \mathrm{ka}$ ) and the Iberian-Roman Humid Period ( $c a 3.5$ to $1.6 \mathrm{ka}$ ) (Cacho et al., 2010), during which the deposits of DEV and AÑA M formed, respectively. The Holocene logs retrieved by Luzón et al. (2011) upstream of Dévanos cover the Medieval Climate Anomaly (1.2 to $0.6 \mathrm{ka}$ ), when a general increase in aridity is recognized throughout the Iberian Peninsula (Moreno et al., 2012).

Although the preserved outcrop records of the Pleistocene and Holocene only appear superposed between the sites of Salto del Cajo (SC) and El Molino (AÑA M), the topography of the fluvial valley and the location of the main springs were probably similar during both epochs. Within this scenario, the lack of Pleistocene tufa and associated carbonate record upstream of Dévanos (as inferred from logged data provided by Luzón et al., 2011 and the absence of tufa outcrops) 
could be related to climate-related parameters. Some studies of present-day fluvial tufa sedimentation in karstic regions demonstrate that the first tufa deposits occur some distance downstream of the headwater karstic springs, depending on the water $\mathrm{pCO}_{2}$-loss that determines the locus from which the Saturation Index of calcite is favourable for calcite precipitation (e.g. Michaelis et al., 1985; Vázquez-Urbez et al., 2011; Auqué et al., 2013). For instance, in the present Añamaza River, tufa precipitation is detected close to the AÑA M site, some $5 \mathrm{~km}$ downstream of the main springs, coinciding with the increase in slope along the valley (Vázquez-Urbez et al., 2011). In addition, the river discharge may also condition the locus from which tufa may begin to form. Drysdale et al. (2002) suggested that, in higher discharge conditions, tufa precipitation would begin further downstream than in lower discharge conditions. According to that report, the overall water discharge of the Pleistocene fluvial systems in the Añamaza valley should have been larger than that of the Holocene system. This is consistent with the frequency of coarse detrital deposits (including trunks and large bedrock fragments) associated with erosional features in the Pleistocene. The stable isotope composition of the Pleistocene samples suggests variable water renewal in the standing water bodies, most probably related to a changing precipitation/evaporation ratio, as discussed above. Moreover, a decrease in the precipitation/evaporation ratio is inferred for the studied Holocene deposits in the Añamaza valley. Overall drier climate conditions have also been reported for the Holocene from lacustrine records in north-east Spain (ValeroGarcés et al., 1998, 2004; Morellón et al., 2009; Moreno et al., 2012) and from stable-isotope and trace elements in other parts of Europe (e.g. Garnett et al., 2004). Smith et al. (2004) deduced more humid conditions during the Pleistocene (MISs 6/5e and prior pluvial phases) than during the Holocene in Egypt, based on stable isotope analyses in tufas. To summarize, the Añamaza valley tufas formed in warm and wet conditions, and record a general decrease in humidity from the Pleistocene to the Holocene.

\section{CONCLUSIONS}

The stratigraphical and sedimentological analyses of the Pleistocene and Holocene tufa deposits of the Añamaza River valley, complemented with chronological and stable isotope data, allow multiple conclusions:

1 Within the Middle-Late Pleistocene, several tufa build-ups (up to $70 \mathrm{~m}$ thick) that consist of one to five depositional stages separated by erosional surfaces are present along the lower stretch of the valley. These stages correlate with marine isotope stages (MISs) 9, 7 and 5. The outcropping Holocene deposits (MIS 1; minimum $10 \mathrm{~m}$ thick) appear encased in pre-Quaternary and Pleistocene deposits along the upper stretch of the valley.

2 Eight fundamental associations of tufa and related facies reveal the existence of a stepped fluvial valley with: (i) steep and low-slope channel reaches (facies Lph, Lbr and Lst 1); (ii) cascades and barrage-cascades (Lbr, Ls, Lph and Lst 2); (iii) dammed areas in channels and pools in the floodplain; (iv) large standing water areas (i.e. shallow lakes) between barrage-cascades (facies Sb, Lb, Li, Lph and M); and (v) zones with abundant hydrophilous plants - in places peaty - of variable extent (Lst $1, \mathrm{M}$ and $\mathrm{Sb}$ ) in the channels, on the floodplain and in the shallow parts of the standing water bodies.

3 A clear separation between a moderately sloped stretch and a highly sloped stretch allows the construction of two conceptual facies models with distinct distributions and extents of the different environments through space. Large, standing or very slow-flowing, in places marshy, water areas separated by barrage-cascade structures characterize the moderate-slope model, in which the abundant phytoherm tufas of stems account for the palustrine conditions. In contrast, in the high-slope model, smaller dammed areas and pools develop between close-up cascade and barrage-cascade structures, and extensive steep reaches with highly irregular floors (for example, ramp-like with stepped cascades: Ls, Lbr and Lph) subject to erosional processes were common, which explains the rarity of preserved phytoherms of stems in those reaches.

The sedimentological and hydrological differences between the Pleistocene and Holocene fluvial systems can be referred, respectively, to the high-slope and moderate-slope models. Nonetheless, these models should be regarded as representative of different depositional contexts that may coexist within a single sedimentation area.

4 The lithological and structural characteristics of the bedrock controlled the different slope of the two stepped stretches/models and the location of the topographical discontinuities 
along the longitudinal profile of the river. The geometry and thickness of the sedimentary fill of the fluvial valley (i.e., depositional units between consecutive knickpoints) are thus distinct for each of the two situations. Larger wedge-shaped units with high $\mathrm{L} / \mathrm{H}$ ratio form in stretches of lower slope, in which a great part of the deposits would correspond to dammed facies. Small wedge-shaped units with low $\mathrm{L} / \mathrm{H}$ ratio develop in stretches of higher slope, generally with less extensive deposits of dammed and palustrine facies. Multi-storey wedge-shaped units consisting of stacked lenticular-shaped and wedge-shaped deposits are more common in steep stretches liable to erosion.

5 The geometry of the steep slope reaches along a river (i.e., knickpoints) conditions the extent and type of facies within the wedge-shaped units. For each geometrical configuration (for example, ramp, single non-vertical step or vertical step), the aggradation/progradation ratio of the tufa deposits (related to changes in the water discharge or water velocity) on such steep surfaces determines the growth style of the cascades or barrage-cascades, and hence the extent, thickness and vertical evolution of deposits in the upstream dammed and gentle-slope river areas.

6 The sedimentological features and stableisotope composition of the carbonate facies suggest a higher, but rather changeable precipitation/ evaporation ratio during the Pleistocene than during the Holocene in this northern part of the Iberian Range. Indeed, the spatial distribution of the tufa deposits suggests that the overall river discharge was larger in the Pleistocene. A decrease in humidity is therefore inferred for the Holocene. This hydrological evolution occurred within the warm context that characterized the Pleistocene and Holocene tufa stages of the Añamaza valley.

7 The different facies and geometrical models proposed in this article may be useful for inferring topographical, hydrological and climatic conditions in other fluvial tufa systems. These results stress the environmental significance of tufas in the geological record, and assess stratigraphical and sedimentological analyses, coupled with stable-isotope data, as crucial tools for such palaeoenvironmental interpretation.

\section{ACKNOWLEDGEMENTS}

This study was funded by projects REN20023575/CLI, CGL2006-05063/BTE and CGL2009-
09216/BTE of the Spanish Government and European Regional Development Fund. It forms part of the research of the Continental Sedimentary Basin Analysis Group and Quaternary Palaeoenvironments Group (Government of AragónUniversity of Zaragoza). We thank the personnel of the Servicio de microscopía electrónica and Servicio de preparación de rocas y materiales duros of SAI of the University of Zaragoza for the technical support. We are grateful to the Editors and reviewers (Drs Pla-Pueyo and Gradzinski) for their meticulous revisions, which helped to improve the manuscript.

\section{REFERENCES}

Andrews, J.E. (2006) Palaeoclimatic records from stable isotopes in riverine tufas: Synthesis and review. Earth-Sci. Rev., 75, 85-104.

Andrews, J.E., Riding, R. and Dennis, P.F. (1997) The stable isotope record of environmental and climatic signals in modern terrestrial microbial carbonates from Europe. Palaeogeogr. Palaeoclimatol. Palaeoecol., 129, 171-189.

Andrews, J.E., Pedley, H.M. and Dennis, P.F. (2000) Palaeoenvironmental records in Holocene Spanish tufas: a stable isotope approach in search of reliable climatic archives. Sedimentology, 47, 961-978.

Arenas, C., Gutiérrez, F., Osácar, C. and Sancho, C. (2000) Sedimentology and geochemistry of fluvio-lacustrine tufa deposits controlled by evaporite solution subsidence in the central Ebro Depresión, NE Spain. Sedimentology, 47, 883-909.

Arenas, C., Cabrera, L. and Ramos, E. (2007) Sedimentology of tufa facies and continental microbialites from the Palaeogene of Mallorca Island (Spain). Sed. Geol., 197, 1-27.

Arenas, C., Sancho, C., Pardo, G., Vázquez-Urbez, M., Osácar, C. and Auqué, L. (2009) Ancient tufas of the Añamaza River (Iberian Ranges, Spain). $27^{\text {th }}$ IAS Meeting of Sedimentology, Alghero, Italy. Book of Abstracts, p. 430, Sassari, Italy.

Arenas, C., Sancho, C., Vázquez-Urbez, M., Pardo, G., Hellstrom, J., Ortiz, J.E., Torres, T., Osácar, C. and Auqué, L. (2010) Las tobas cuaternarias del río Añamaza (provincia de Soria, Cordillera Ibérica): aproximación cronológica. Geogaceta, 49, 51-54.

Arenas, C., Vázquez-Urbez, M., Auqué, L., Sancho, C., Osácar, C. and Pardo, G. (2014) Intrinsic and extrinsic controls of spatial and temporal variations in modern fluvial tufa sedimentation: A thirteen-year record from a semi-arid environment. Sedimentology, (in press). doi: 10. 1111/sed.12045.

Arenas-Abad, C., Vázquez-Urbez, M., Pardo-Tirapu, G. and Sancho-Marcén, C. (2010) Fluvial and associated carbonate deposits. In: Carbonates in Continental Settings: Facies, Environments and Processes (Eds A.M. Alonso-Zarza and L.H. Tanner), Dev. Sedimentol., 61, 133-175. Elsevier, Amsterdam, The Netherlands.

Auqué, L., Arenas, C., Osácar, C., Pardo, G., Sancho, C. and Vázquez-Urbez, M. (2013) Tufa sedimentation in changing hydrological conditions: the River Mesa (Spain). Geol. Acta, 11, 85-102. 
Benito, G., Sancho, C., Peña, J.L., Machado, M.J. and Rhodes, E.J. (2010) Large-scale karst subsidence and accelerated fluvial aggradation during MIS 6 in NE Spain: climatic and paleohydrological implications. Quatern. Sci. Rev., 29, 2694-2704.

Berger, A. and Loutre, M.F. (1991) Insolation values for the climate of the last 10 million years. Quatern. Sci. Rev., 10, 297-317.

Cacho, I., Valero-Garcés, B. and González-Sampériz, P. (2010) Review of paleoclimate reconstructions in the Iberian Peninsula since the last glacial period. In: Report: Climate in Spain: Past, present and future (Eds F.F. Pérez and R. Boscolo), pp. 9-24. Red Temática Clivar-España, Madrid, Spain.

Candy, I., Adamson, K., Gallant, C.E., Whitfield, E. and Pope, R. (2012) Oxygen and carbon isotopic composition of Quaternary meteoric carbonates from western and southern Europe: Their role in palaeoenvironmental reconstruction. Palaeogeogr. Palaeoclimatol. Palaeoecol., 326-328, 1-11.

Capezzuoli, E., Gandin, A. and Pedley, H.M. (2009) Travertines and calcareous tufa in Tuscany (Central Italy). 27th IAS Meeting of Sedimentology, Alghero, Italy. Fieldtrip Guidebook, pp. 129-158, Sassari, Italy.

Carthew, K.D., Taylor, M.P. and Drysdale, R.N. (2003) Are current models of tufa sedimentary environments applicable to tropical systems? A case study from the Gregory River. Sed. Geol., 162, 199-218.

Carthew, K.D., Taylor, M.P. and Drysdale, R.N. (2006) An environmental model of fluvial tufas in the monsoonal tropics, Barkly karst, northern Australia. Geomorphology, 73, 78-100.

Coloma, P., Martínez, F.J. and Sánchez, J.A. (1996) La Laguna de Añavieja. Funcionamiento y génesis. Geogaceta, 20, 1258-1260.

D'Argenio, B. and Ferreri, V. (1988) Ambienti di deposizione e litofacies dei travertine quaternary dell'Italia centro-meridionale. Mem. Soc. Geol. Italia, 41, 861-868.

Domínguez-Villar, D., Vázquez-Navarro, J.A., Cheng, H. and Edwards, R.L. (2011) Freshwater tufa record from Spain supports evidence for the past interglacial being wetter than the Holocene in the Mediterranean region. Global Planet. Change, 77, 129-141.

Drysdale, R. and Gillieson, D. (1997) Micro-erosion meter measurements of travertine deposition rates: a case study from Louie Creek, northwest Queensland, Australia. Earth Surf. Proc. Land., 22, 1037-1051.

Drysdale, R.N., Taylor, M.P. and Ihlenfeld, C. (2002) Factors controlling the chemical evolution of travertine-depositing rivers of the Barkly karst, Northern Australia. Hydrol. Process., 16, 2941-2962.

Durán, J.J. (1989) Geocronología de los depósitos asociados al karst en España. In: El Karst en España (Eds J.J. Durán and J. Martínez), Monografía Sociedad Española de Geomorfología, 4, 243-256, Sociedad Española de Geomorfología, Madrid, Spain.

Ford, T.D. and Pedley, H.M. (1996) A review of tufa and travertine deposits of the world. Earth-Sci. Rev., 41, 117-175.

Frank, N., Braum, M., Hambach, U., Mangini, A. and Wagner, G. (2000) Warm Period Growth of Travertine during the Last Interglaciation in Southern Germany. Quatern. Res., 54, 38-48.

Fuller, I.C., Macklin, M.G., Lewin, J., Passmore, D.G. and Wintle, A.G. (1998) River response to high-frequency climate oscillations in southern Europe over the past 200 k.y. Geology, 26, 275-278.
García del Cura, M.A., González-Martín, J.A. and Ordóñez, S. (1997) El sistema de represas tobáceas poco evolucionadas del río Arquillo (Alcaraz-Albacete). Cuad. Geol. Ibérica, 22, 321-332.

García-Ruiz, J.M., Martí-Bono, C., Peña-Monné, J.L., Sancho, C., Rhodes, E.J., Valero-Garcés, B., González-Sampériz, P. and Moreno, A. (2013) Glacial and fluvial deposits in the Aragón Valley, Central-Western Pyrenees: Chronology of the Pyrenean Late Pleistocene glaciers. Geogr. Ann., Series A, Phys. Geogr. 95, 15-32.

Garnett, E.R., Andrews, J.E., Preece, R.C. and Dennis, P.F. (2004) Climatic change recorded by stable isotopes and trace elements in a British Holocene tufa. J. Quatern. Sci., 19, 251-262.

Gibbard, P.L., Boreham, S., Cohen, K.M. and Moscariello, A. (2005) Global chronostratigraphical correlation table for the last 2.7 million years. Boreas, 34.

Golubić, S. (1969) Cyclic and noncyclic mechanisms in the formation of travertine. Verb. Inernat. Verein. Limnol., 17, 956-961.

Goudie, A.S., Viles, H.A. and Pentecost, A. (1993) The lateHolocene tufa decline in Europe. Holocene, 3, 181-186.

Gradziński, M. (2010) Factors controlling growth of modern tufa: results of a field experiment. In: Tufas and Speleothems: Unravelling the Microbial and Physical Controls, pp. 143-191. (Eds M. Pedley and M. Rogerson), Geological Society, London.

Guerrero-Domínguez, L. and González-Martín, J.A. (2000) Características geomorfológicas del modelo de construcción tobáceo del Alto Tajo en su fondo de valle (Peralejos de las Truchas-Guadalajara). Geotemas, 1, 375-378.

Hennig, G.J., Grun, R. and Brunnacker, K. (1983) Speleothems, travertins and paleoclimates. Quatern. Res., 20, 1-29.

Horvatinčić, N., Krajcar Bronić, I. and Obelić, B. (2003) Differences in the ${ }^{14} \mathrm{C}$ age, $\delta^{13} \mathrm{C}$ and $\mathrm{N}^{18} \mathrm{O}$ of Holocene tufa and speleothem in the Dinaric Karst. Palaeogeogr. Palaeoclimatol. Palaeoecol., 193, 139-157.

Leng, M.J. and Marshall, J.D. (2004) Palaeoclimate interpretation of stable isotope data from lake sediment archives. Quatern. Sci. Rev., 23, 811-831.

Lewis, C., McDonald, E., Sancho, C., Peña, J.L. and Rhodes, E. (2009) Climatic implications of correlated Upper Pleistocene glacial and fluvial deposits on the Cinca and Gállego Rivers (NE Spain) based on OSL dating and soil stratigraphy. Global Planet. Change, 67, 141-152.

Lojen, S., Dolenec, T., Vokal, B., Cukrov, N., Mihelčić, G. and Papesch, W. (2004) C and O stable isotope variability in recent freshwater carbonates (River Krka, Croatia). Sedimentology, 51, 361-375.

Lozano, M.V., Sancho, C., Arenas, C., Vázquez-Urbez, M., Ortiz, J.E., Torres, T., Pardo, G., Osácar, M.C. and Auqué, L. (2012) Análisis preliminar de las tobas cuaternarias del río Ebrón (Castielfabib, Valencia, Cordillera Ibérica). Geogaceta, 51, 51-54.

Luzón, M.A., Pérez, A., González, A., Sánchez, J.A., Coloma, P. and Soria, A.R. (2008) Caracterización sedimentaria de los depósitos holocenos de la laguna de Añavieja (Soria). NE de España. Geo-Temas, 10, 207-210.

Luzón, M.A., Pérez, A., Borrego, A.G., Mayayo, M.J. and Soria, A.R. (2011) Interrelated continental sedimentary environments in the central Iberian Range (Spain): Facies characterization and main palaeoenvironmental changes during the Holocene. Sed. Geol., 239, 87-103.

Martín-Algarra, A., Martín-Marín, M., Andreo, B., Julià, R. and González-Gómez, C. (2003) Sedimentary patterns in perched spring travertines near Granada (Spain) as 
indicators of the paleohydrological and paleoclima-tological evolution of a karst massif. Sed. Geol., 161, 217-228.

Martínez-Tudela, A., Cuenca, F., Santisteban, C., Grun, R. and Hentzsch, B. (1986) Los travertinos del Río Matarraña, Beceite (Teruel) como indicadores paleoclimáticos del Cuaternario. In: Quaternary Climate in Western Mediterranean, pp. 307-324. (Ed A. López-Vera), Universidad Autónoma de Madrid, Madrid, Spain.

Mas, R., Benito, M.J., Arribas, J., Alonso, A., Arribas, M.E., Lohmann, K., González-Acebrón, L., Hernán, J., Quijada, E., Suárez, P. and Omodeo, S. (2011) Evolution of an intraplate rift basin: the Latest Jurassic-Early Cretaceous Cameros Basin (Northwest Iberian Ranges, North Spain). In: Geo-Guías, 8. Post-meeting field trips Guidebook, 28th IAS meeting, pp. 117-154. (Eds C. Arenas, L. Pomar and F. Colombo), Sociedad Geológica de España, Zaragoza, Spain.

McCrea, J.M. (1950) On the isotope chemistry of carbonates and a paleotemperature Scale. J. Chem. Phys., 18, 849-587.

Michaelis, J., Usdowski, E. and Menschel, G. (1985) Partitioning of ${ }^{13} \mathrm{C}$ and ${ }^{12} \mathrm{C}$ on the degassing of $\mathrm{CO}_{2}$ and the precipitation of calcite-Rayleigh-type fractionation and a kinetic model. Am. J. Sci., 285, 318-327.

Morellón, M., Valero-Garcés, B., Vegas-Vilarrúbia, T., Conzález-Sampériz, P., Romero, O., Delgado-Huertas, A., Mata, P., Moreno, A., Rico, M. and Corella, J.P. (2009) Lateglacial and Holocene palaeohydrology in the western Mediterranean region: the Lake Estanya record (NE Spain). Quatern. Sci. Rev., 28, 2582-2599.

Moreno, A., Pérez, A., Frigola, J., Nieto-Moreno, V., Rodrigo-Gámiz, M., Martrat, B., González-Sampériz, P., Morellón, M., Martín-Puertas, C., Corella, J.P., Belmonte, A., Sancho, C., Cacho, I., Herrera, G., Canals, M., Grimalt, J.O., Jiménez-Espejo, F.J., Martinez-Ruiz, F.C., Vegas-Vilarrúbia, T. and Valero-Garcés, B.L. (2012) The Medieval Climate Anomaly in the Iberian Peninsula reconstructed from marine and lake records. Quatern. Sci. Rev., 43, 16-32.

Ordóñez, S. and García del Cura, M.A. (1983) Recent and Tertiary fluvial carbonates in central Spain. In: Ancient and Modern Fluvial Systems (Eds J.D. Collinson and J. Lewin), Special Publication, International Association of Sedimentologits, 6, 485-497. Blackwell, Oxford, United Kingdom.

Ordóñez, S., González Martín, J.A. and García del Cura, M.A. (1986) Pétrographie and morphologie des édifices tuffeux quaternaires du centre de l'Espagne. Mediterranée, 57, 51-60.

Ordóñez, S., González Martín, J.A., García del Cura, M.A. and Pedley, H.M. (2005) Temperate and semi-arid tufas in the Pleistocene to Recent fluvial barrage system in the Mediterranean area: the Ruidera Lakes Natural Park (central Spain). Geomorphology, 69, 332-350.

Ortiz, J.E., Torres, T., Delgado, A., Reyes, E. and DíazBautista, A. (2009) A review of the Tagus river tufa deposits (central Spain): age and palaeoenvironmental record. Quatern. Sci. Rev., 28, 947-963.

Osácar, M.C., Arenas, C., Vazquez-Urbez, M., Sancho, C., Auque, L.F. and Pardo, G. (2013) Environmental Factors Controlling the $\delta 13 \mathrm{C}$ and $\delta 18 \mathrm{O}$ Variations of Recent Fluvial Tufas: A 12-Year Record from the Monasterio de Piedra Natural Park (Ne Iberian Peninsula). J. Sed. Res., 83, 309-322.

Pedley, H.M. (1990) Classification and environmental models of cool freshwater tufas. Sed. Geol., 68, 143-154.

Pedley, H.M. (2009) Tufas and travertines of the Mediterranean region: a testing ground for freshwater carbonate concepts and developments. Sedimentology, 56, 221-246.
Pedley, H.M., Andrews, J., Ordóñez, A., García del Cura, M.A., González-Martín, J.A. and Taylor, D. (1996) Does climate control the morphological fabric of freshwater carbonates? A comparative study of Holocene barrage tufas from Spain and Britain. Palaeogeogr. Palaeoclimatol. Palaeoecol., 121, 239-257.

Pedley, H.M., Hill, I., Denton, P. and Brasington, J. (2000) Three-dimensional modelling of a Holocene tufa system in the Lathkill Valley, north Derbyshire, using groundpenetrating radar. Sedimentology, 47, 731-737.

Pedley, H.M., González-Martín, J.A., Ordóñez, S. and García del Cura, M.A. (2003) Sedimentology of Quaternary perched springline and paludal tufas: criteria for recognition, with examples from Guadalajara Province, Spain. Sedimentology, 50, 23-44.

Peña, J.L., Sancho, C. and Lozano, M.V. (2000) Climatic and tectonic significance of Late Pleistocene and Holocene tufa deposits in the Mijares River Canyon, eastern Iberian Range, northeast Spain. Earth Surf. Proc. Land., 25, 14031417.

Pentecost, A. (1978) Blue-green algae and freshwater carbonate deposits. Proc. R. Soc. London, 200, 43-61.

Pentecost, A. (1995) The Quaternary travertine deposits of Europe and Asia Minor. Quatern. Sci. Rev., 14, 1005-1028.

Pentecost, A. and Viles, H. (1994) A Review and Reassessment of Travertine Classification. Géog. Phys. Quatern., 48, 305-314.

Pérez, A., Luzón, A., Soria, A.R., Borrego, A.G., Holmes, J. and Mayayo, M.J. (2010) El sistema fluvio-lacustre de Añavieja: facies y evolución sedimentaria durante el Holoceno. Cordillera Ibérica. NE de España. Geogaceta, 48, $39-42$.

Rey de la Rosa, J. and Rivera-Navarro, S. (1981) Mapa Geológico 1:50000 y memoria explicativa de la hoja 319 (Ágreda). Servicio de publicaciones del Ministerio de Industria. IGME, Madrid, $24 \mathrm{pp}$.

Sáenz-Ridruejo, C. and Sanz-Pérez, E. (1989) La Laguna de Añavieja. Turiaso, 9, 225-243.

Sancho, C., Peña, J.L. and Meléndez, A. (1997) Controls on Holocene and present-day travertine formation in the Guadalaviar River (Iberian Chain, NE Spain). Z. Geomorphol., 41, 289-307.

Sancho, C., Arenas, C., Pardo, G., Vázquez, M., Hellstrom, J., Ortiz, J.E., Rhodes, E.J., Osácar, C. and Auqué, L. (2010) Ensayo cronológico de las tobas cuaternarias del río Piedra (Cordillera Ibérica). Geogaceta, 48, 31-34.

Shackleton, N.J. and Opdyke, N.D. (1973) Oxygen isotope and paleomagnetic stratigraphy of Equatorial Pacific core V28-238: oxygen isotope temperatures and ice volumes on a $10^{5}$ year and $10^{6}$ year scale. Quarter. Res., 3, 39-55.

Smith, J.R., Giegengack, R. and Schwarcz, H.P. (2004) Constraints on Pleistocene pluvial climates through stableisotope analysis of fossil-spring tufas and associated gastropods, Kharga Oasis, Egypt. Palaeogeogr. Palaeoclimatol. Palaeoecol., 206, 157-175.

Talbot, M.E. and Kelts, K. (1990) Paleolimnological signatures from carbon and oxygen isotopic ratios in carbonates from organic-rich lacustrine sediments. In: Lacustrine exploration: case studies and modern analogues (Ed. B.J. Katz), AAPG special volumes, 50, 99112. Tulsa, Oklahoma, USA.

Valero-Garcés, B., Zeroual, E. and Kelts, K. (1998) Arid phases in the western Mediterranean region during the last glacial cycle reconstructed from lacustrine records. In: Palaeohydrology and Environmental Change, pp. 67-80. 
(Eds G. Benito, V.R. Baker and K.J. Gregory), John Willey and Sons, Chichester, UK.

Valero-Garcés, B.L., González-Sampériz, P., Navas, A., Machín, J., Delgado-Huertas, A., Peña-Monné, J.L., Sánchez-Marcén, C., Stevenson, T. and Davis, B. (2004) Paleohydrological fluctuations and steppe vegetation during the last glacial maximum in the central Ebro valley (NE Spain). Quatern. Int., 122, 43-55.

Valero-Garcés, B.L., Moreno, A., Navas, A., Mata, P., Machín, J., Delgado-Huertas, A., González-Sampériz, P., Schwalb, A., Morellón, M., Cheng, H. and Edwards, A. (2008) The Taravilla lake and tufa deposits (Central Iberian Range, Spain) as palaeohydrological and palaeoclimatic indicators. Palaeogeogr. Palaeoclimatol. Palaeoecol., 259, 136-156.

Vázquez-Urbez, M. (2008) Caracterización y significado ambiental de depósitos tobáceos neógenos de la Cuenca del Ebro. Comparación con ambientes Cuaternarios. PhD thesis, Universidad de Zaragoza, Spain, 476 pp. http:// zaguan.unizar.es/record/2057/files/TESIS-2009-038.pdf

Vázquez-Urbez, M., Arenas, C., Sancho, C., Osácar, C., Auqué, L. and Pardo, G. (2010) Factors controlling presentday tufa dynamics in the Monaterio de Piedra Natural Park (Iberian Range, Spain): depositional environmental settings, sedimentation rates and hydrochemistry. Int. J. Earth Sci. (Geol. Rundsch.), 99, 1027-1049.

Vázquez-Urbez, M., Arenas, C., Sancho, C., Auqué, L., Osácar, C. and Pardo, G. (2011) Quaternary and presentday tufa systems of the Piedra and Añamaza rivers (Iberian Range, Spain). In: Geo-Guías, 8. Post-meeting field trips Guidebook, 28th IAS meeting, pp. 241-274. (Eds C. Arenas, L. Pomar and F. Colombo), Sociedad Geológica de España, Zaragoza, Spain.
Vázquez-Urbez, M., Arenas, C. and Pardo, G. (2012) A sedimentary facies model for stepped, fluvial tufa systems in the Iberian Range (Spain): the Quaternary Piedra and Mesa valleys. Sedimentology, 59, 502-526.

Viles, H.A. and Goudie, A.S. (1990) Tufas, travertines and allied carbonate deposits. Prog. Phys. Geogr., 14, 19-41.

Viles, H.A. and Pentecost, A. (1999) Geomorphological controls on tufa deposition at Nash Brook, South Wales, United Kingdom. Cave Karst Sci., 26, 61-68.

Viles, H.A. and Pentecost, A. (2007) Tufa and travertine. In: Geochemical Sediments and Landscape, pp. 173-199. (Eds D. Nash and S. McLaren), Blackwell, Oxford, United Kingdom.

Viles, H.A., Taylor, M.P., Nicoll, K. and Neumann, S. (2007) Facies evidence of hydroclimatic regime shifts in tufa depositional sequences from the arid Naukluft Mountains, Namibia. Sed. Geol., 195, 39-53.

Violante, C., Ferreri, V., D'Argenio, B. and Golubic, S. (1994) Quaternary travertines at Rocchetta a Volturno (Iserna, central Italy). Facies analysis and sedimentary model of an organogenic carbonate system. 15th IAS Regional Meeting, Fieldtrip Guidebook, pp. 5-23, Ischia, Italy.

Weijermars, R., Mulder-Blanken, C.W. and Wiegers, J. (1986) Growth rate observation from the moss-built Chela travertine terrace, central Spain. Geol. Mag., 123, 279286.

Manuscript received 5 July 2012; revision accepted 9 April 2013 